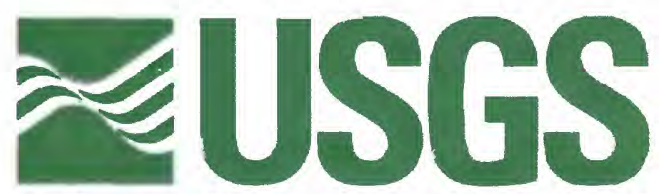

science for a changing world

In ccoperation with the U.S. Environmental Protection Agency, Office of Ground Water \& Drinking Water

\title{
Data from Archived Chromatograms on Halogenated Volatile Organic Compounds in Untreated Ground Water used for Drinking Water in the United States, 1997-2000
}

Open-File Report 03-352 
U.S. Department of the Interior

U.S. Geological Survey

\section{Data from Archived Chromatograms on Halogenated Volatile Organic Compounds in Untreated Ground Water used for Drinking Water in The United States, 1997-2000}

By Stephanie Dunkle Shapiro, Eurybiades Busenberg, L. Niel Plummer, and Michael J. Focazio

Open-File Report 03-352

Prepared in cooperation with the

U.S. Environmental Protection Agency, Office of Ground Water \& Drinking Water 


\title{
U.S. DEPARTMENT OF THE INTERIOR \\ GALE A. NORTON, Secretary
}

\author{
U.S. GEOLOGICAL SURVEY \\ Charles G. Groat, Director
}

The use of trade, product, or firm names in this publication is for descriptive purposes only and does not imply endorsement by the U.S. Government.

For additional information contact:

Chief, Branch of Regional Research, Eastern

Copies of this report can be purchased from:

Region

U.S. Geological Survey

MS 432

12201 Sunrise Valley Drive

Reston, VA 20192
U.S. Geological Survey

Information Services

Box 25286, Federal Center

Denver, CO 80225

e-mail: infoservices@usgs.gov 


\section{CONTENTS}

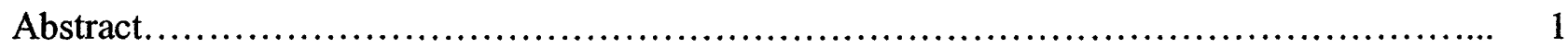

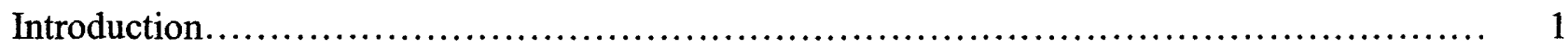

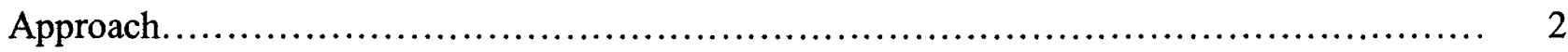

Data on VOC Detections................................................................. 3

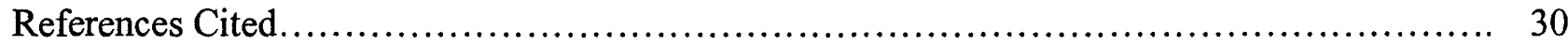

\section{Tables}

Table 1. Field information for all sites included in this report............................... 4

Table 2. Codes used in table 1 developed by the U.S. Geological Survey CFC Laboratory to aid in the interpretation of CFC-modeled ages................................... 13

Table 3. CFC and VOC data for all sites included in this report............................. 14 


\section{Abbreviations and Acronyms}

$\begin{array}{ll}\text { CFC } & \text { Chlorofluorocarbon } \\ \text { CFC-11 } & \text { Trichloromonofluoromethane } \\ \text { CFC-12 } & \text { Dichlorodifluoromethane } \\ \text { CFC-113 } & \text { 1,1,2-trichloro-1,2,2-trifluoroethane } \\ \text { GC-ECD } & \text { Gas Chromatograph-Electron Capture Detector } \\ \text { USGS } & \text { United States Geological Survey } \\ \text { VOC } & \text { Volatile Organic Compound } \\ \mu \mathrm{g} / \mathrm{L} & \text { Micrograms per liter } \\ \mathrm{pg} / \mathrm{kg} & \text { Picograms per kilogram }\end{array}$




\title{
Data from Archived Chromatograms on Halogenated Volatile Organic Compounds in Untreated Ground Water Used for Drinking Water in the United States, 1997-2000
}

\author{
By Stephanie Dunkle Shapiro, Eurybiades Busenberg, L. Niel Plummer, and \\ Michael J. Focazio
}

\section{ABSTRACT}

This report presents tables of data that are discussed and interpreted in a companion report (Shapiro and others, in press). Data on the frequency of detection of halogenated volatile organic compounds (VOCs) in drinking-water sources were compiled from archived chromatograms from samples analyzed originally for chlorofluorocarbons (CFCs) by purge-and-trap gas chromatography with an electron-capture detector. CFC concentrations and VOC peaks, including trace detections, are reported from samples of raw, untreated, drinking water from 413 ground-water wells or springs in 19 states. The samples were collected and then analyzed in the U.S. Geological Survey CFC Laboratory from 1997 through 2000. The subset of data used in this investigation is internally consistent with respect to sampling and analysis. Modeled piston-flow groundwater residence times are assigned to each sample based on dichlorodifluoromethane concentrations. The data can be used to help evaluate the impact of anthropogenic activity on drinking water from ground-water sources in the U.S.

\section{INTRODUCTION}

Recent surveys have focused on characterizing the extent of volatile organic compound (VOC) contamination in ground water (Westrick, 1990; Bender and others, 1999; Moran and others, 1999; Squillace and others, 1999; Lapham and others, 2000; Rowe and others, 2001; Zogorski and others, 2001; Shapiro and others, 2002; Moran and others, 2002; Squillace and others, 2002; Stackelberg and others, 2000). Shapiro and others (2002) showed that the percentage of drinking-water sites containing at least trace concentrations of one VOC was significantly larger than previously recognized when the detection limit is reduced (Mlay 1990; Squillace and others, 1999; Squillace and others, 2002). Shapiro and others (in press) evaluated the occurrence of selected halogenated VOCs at a detection limit of $10^{-6} \mu \mathrm{g} / \mathrm{L}$ in water samples taken from community-, non-community(such as restaurants), and domestic-supply wells throughout the U.S. In addition, Shapiro and others (in press) used modeled pistonflow ground-water residence times, determined from concentrations of dichlorodifluoromethane (CFC-12), to assess historical trends in the detection frequency and the magnitude of VOC concentrations for all the VOCs combined, and for selected VOCs, such as carbon tetrachloride $\left(\mathrm{CCl}_{4}\right)$, chloroform, and tetrachloroethene (PCE).

The purpose of this report is to present data that are discussed and interpreted in a companion report (Shapiro and others, in press). The data presented in this report are 
internally consistent with respect to sampling and analysis and are not affected by the analytical complications that affected the data in Shapiro and others (2002). The samples were all analyzed on the same instrument, with analysis times of 18 minutes or greater, and when instrument conditions remained relatively stable (see the discussion of laboratory conditions in Shapiro and others, 2002). In addition, the data set in this report includes trace VOC peaks and modeled piston-flow ground-water recharge years for each sample based on dichlorodifluoromethane (CFC-12) concentrations that were not included in Shapiro and others (2002).

\section{APPROACH}

The data compiled by Shapiro and others (2002) were obtained from archived chromatograms that were originally used to measure concentrations of CFC-12, trichloromonofluoromethane (CFC-11), and 1,1,2-trichloro-1,2,2-trifluoroethane (CFC113) in water samples by purge-and-trap gas chromatography with an electron capture detector (GC-ECD). These analyses were performed in the United States Geological Survey (USGS) Chlorofluorocarbon (CFC) Laboratory, in Reston, VA. The analytical detection limit for CFCs is somewhat variable depending on laboratory and sample conditions, but was in the range of 0.3 to 1.0 picograms per kilogram of water $\left(0.3 \times 10^{-12}\right.$ to $1.0 \times 10^{-12}$ grams per kilogram, or 0.3 to 1.0 parts per quadrillion). The CFC concentrations can be converted to atmospheric partial pressures using Henry's Law and can be related to historic atmospheric concentrations of CFCs to estimate the apparent year a water sample was recharged to a ground-water-flow system (Busenberg and Plummer, 1992; Plummer and Friedman, 1999; Plummer and Busenberg, 2000; http://water.usgs.gov/lab/cfc (accessed on July 31, 2003)).
Because of the sensitivity of the GC-ECD to halogenated VOCs (such as CFC-11, CFC-12 and CFC-113), the archived chromatograms from the USGS CFC Laboratory include information on the occurrence of a variety of other halogenated VOCs (such as $\mathrm{CCl}_{4}$, chloroform, and PCE) that can be used to assess the occurrence of VOCs in ground water (Shapiro and others, 2002). It is difficult to specify that a given peak appearing on a CFC chromatogram is a particular compound due to the lack of standards used in the CFC Laboratory for specific VOCs other than the CFCs and to variations in the conditions of the instrument over time. However, certain VOCs that routinely appear on the chromatograms have been identified on the basis of a limited number of VOC standards used periodically (Shapiro and others, 2002). The exact concentration of these VOCs cannot be ascertained from the archived chromatograms because the standards were not routinely utilized for VOCs other than CFC-11, CFC-12 and CFC-113. Nevertheless, the peak areas associated with the elution times of other VOCs on the chromatograms can be classified qualitatively to assess a range in the concentrations between the lower detection limit of parts per quadrillion and the upper detection limit of parts per billion $\left(10^{-3} \mu \mathrm{g} / \mathrm{L}\right)$. The exact range will depend on the specific VOC under consideration (see Shapiro and others, 2002 for a more detailed discussion). The USGS CFC Laboratory does not accept samples from wells that have known contamination with VOCs, because such samples saturate the GC-ECD system and disrupt the measurements of CFCs.

Therefore, the archived chromatograms from the USGS CFC Laboratory did not include many samples with maximum contaminant level (MCL) violations, and the drinkingwater samples used in this survey have not been impacted by known accidental releases of VOCs to the ground water. 
In Shapiro and others (2002), peak areas on the GC-ECD chromatograms were classified as ' $S$ ' (small), ' $M$ ' (medium), and ' $\mathrm{L}$ ' (large), corresponding to peak areas of 100,000-499,999 counts, 500,000-999,999 counts, and $1,000,000$ or more counts, respectively. In this report, the additional classification of 'VS' (very small) is also included for peak areas on the archived GC-ECD chromatogram of less than 100,000 counts. Such peaks are discernible on the archived chromatograms and routinely used to evaluate concentrations in water in parts per quadrillion of CFC-11, CFC-12 and CFC-113. The addition of the 'VS' peaks in this investigation was necessary for additional interpretation of atmospheric inputs of VOCs to ground water as discussed in Shapiro and others (in press).

This report uses a subset of the data compiled by Shapiro et al. (2002) consisting of analyses of samples from 413 ground-water wells or springs that were a source of untreated drinking water. The water samples were collected from community-, noncommunity- (such as restaurants), and domestic-supply wells throughout the U.S. from 1997 through 2000, using metal discharge tubing, and were fused in borosilicate ampoules without contacting air (Busenberg and Plummer, 1992). The samples were all analyzed on the same instrument, with analysis times of 18 minutes or greater, and when instrument conditions remained relatively stable (see the discussion of laboratory conditions in Shapiro and others, 2002). The data presented in this report, and interpreted in Shapiro and others (in press), are internally consistent and are not affected by the analytical complications that affected the data in Shapiro and others (2002). In addition, the data set in this report includes the 'VS' VOC peaks discussed above, and modeled piston-flow ground-water recharge years for each sample based on dichlorodifluoromethane (CFC-12) concentrations.
Concentrations of $\mathrm{CFC}-12$ were used in this investigation to estimate the modeled recharge year because CFC-12 appears to the most stable of the three CFC tracers used in dating water (Busenberg and Plummer, 1992; Plummer and Friedman, 1999; Plummer and Busenberg, 2000; http://water.usgs.gov/lab/cfc (accessed on July 31, 2003)).

\section{DATA ON VOC DETECTIONS}

Field information for the 413 groundwater sites is presented in Table 1. This information has been published previously as part of the larger data set included in Shapiro and others (2002). The data are republished here, but limited to only those sites included in the companion report (Shapiro and others, in press). Information presented for each site includes, where available, state location, depth of well, length of open interval, land-surface elevation, water temperature, ground-water use, local land use, geochemical conditions during sampling, hydrologic conditions, sampling method and field conditions, materials that contacted the sample, and other ancillary data. Not all information was available for each site. Categories such as ground-water use, local land use, geochemical conditions during sampling, hydrologic conditions, sampling method, field conditions, and materials that contacted the sample were populated using codes developed by the USGS Chlorofluorocarbon Laboratory to aid in the interpretation of CFC concentrations. These codes are shown in Table 2. The counter utilized in Table 1 is the same as that used in Shapiro and others (2002). Table 3 includes $\mathrm{CFC}$ and VOC data, including CFC$11, \mathrm{CFC}-12$, and CFC-113 concentrations and peak areas, CFC-12 modeled recharge years, and the elution times and peak areas for each VOC peak detected. The same counter that is utilized in Table 1, and in Shapiro and others (2002), is also used in Table 3. 


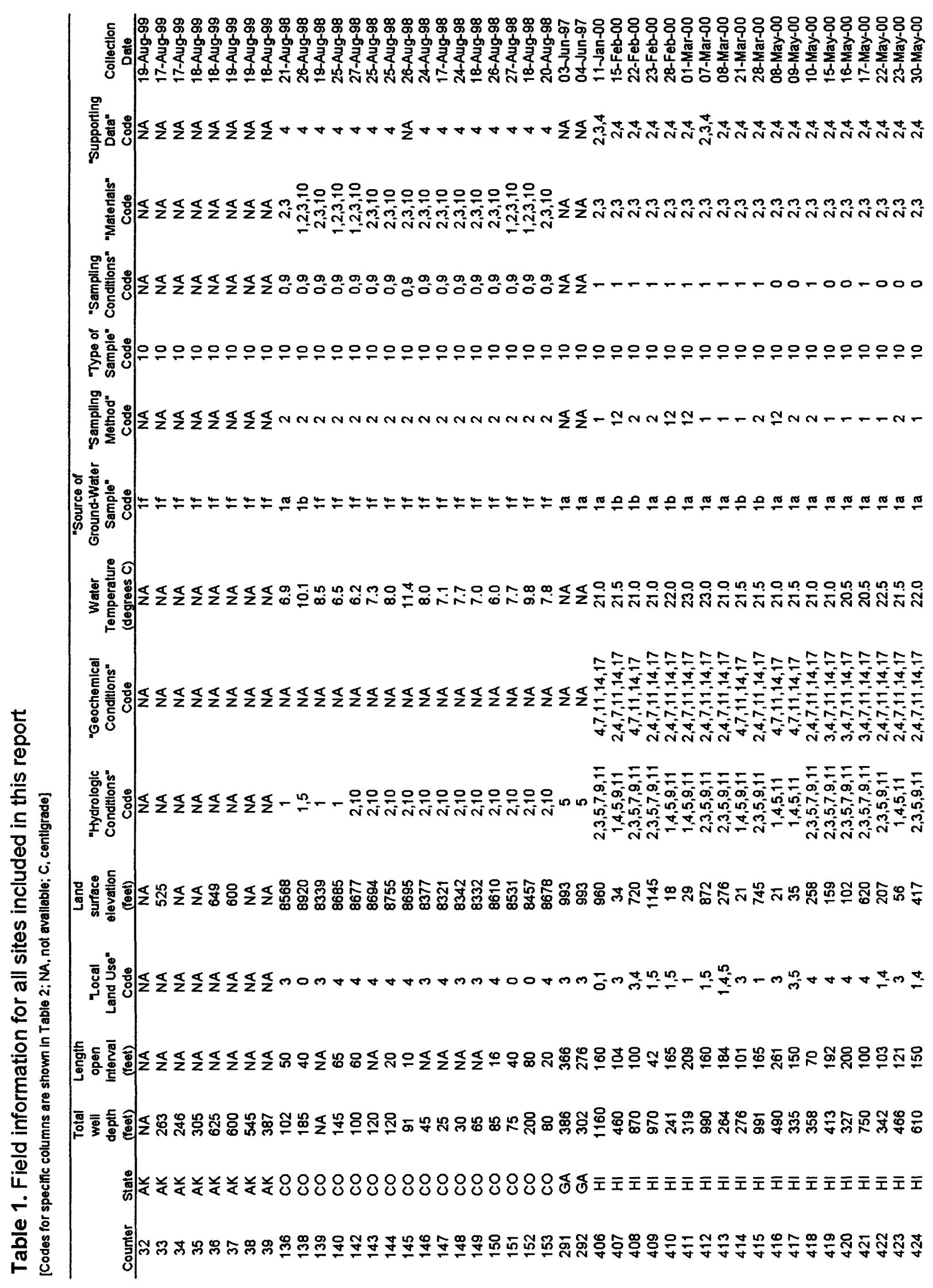




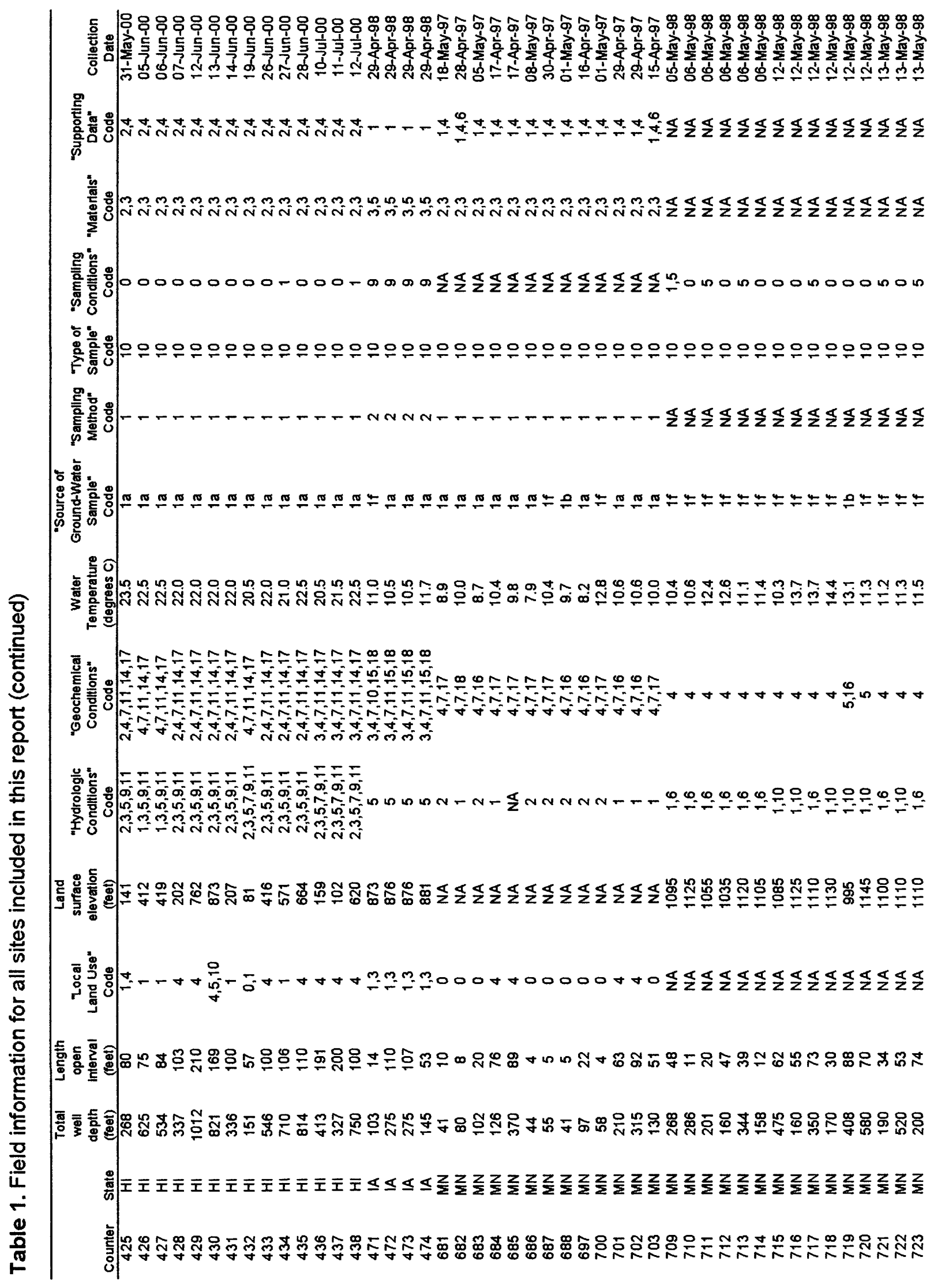




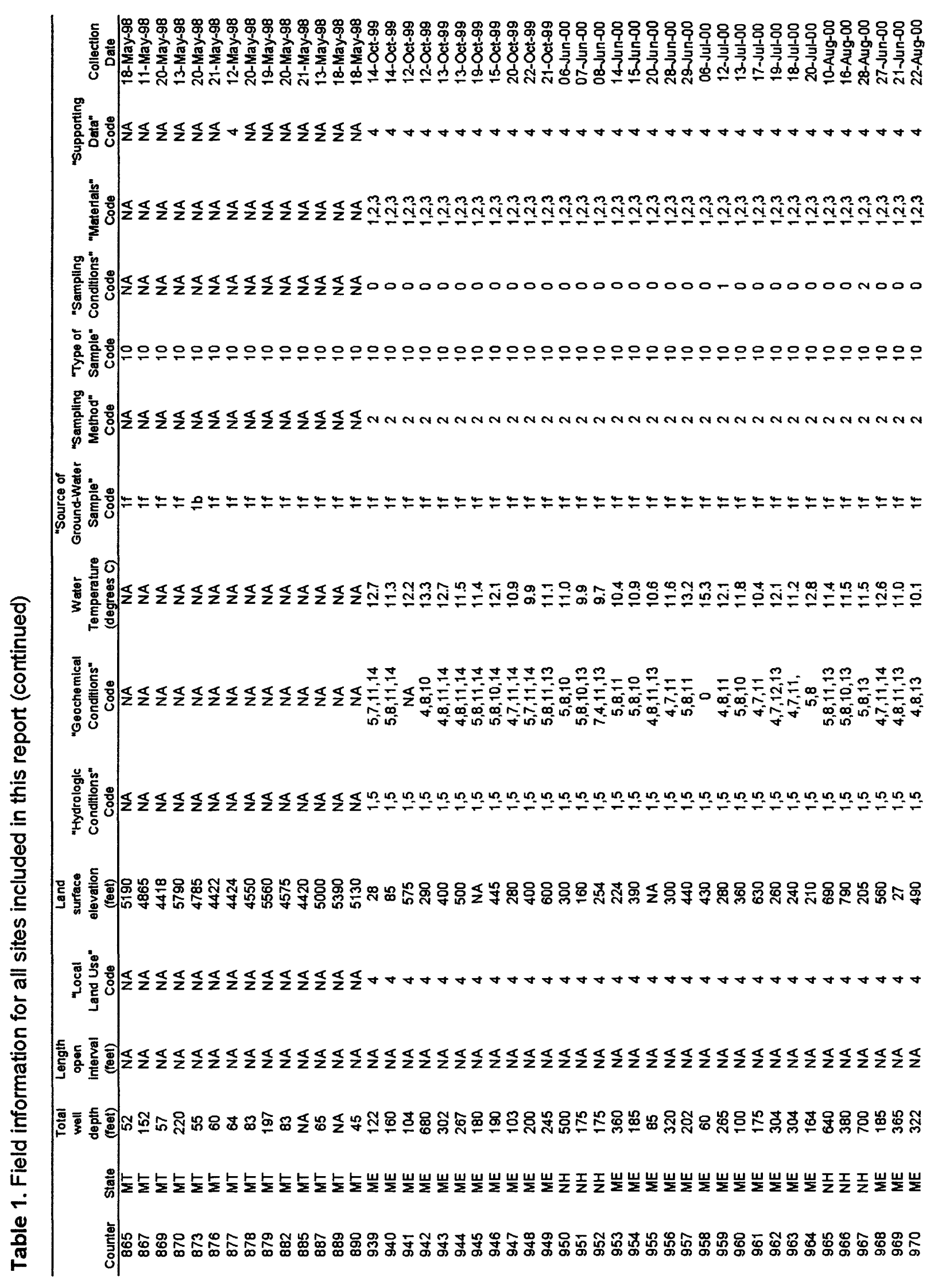




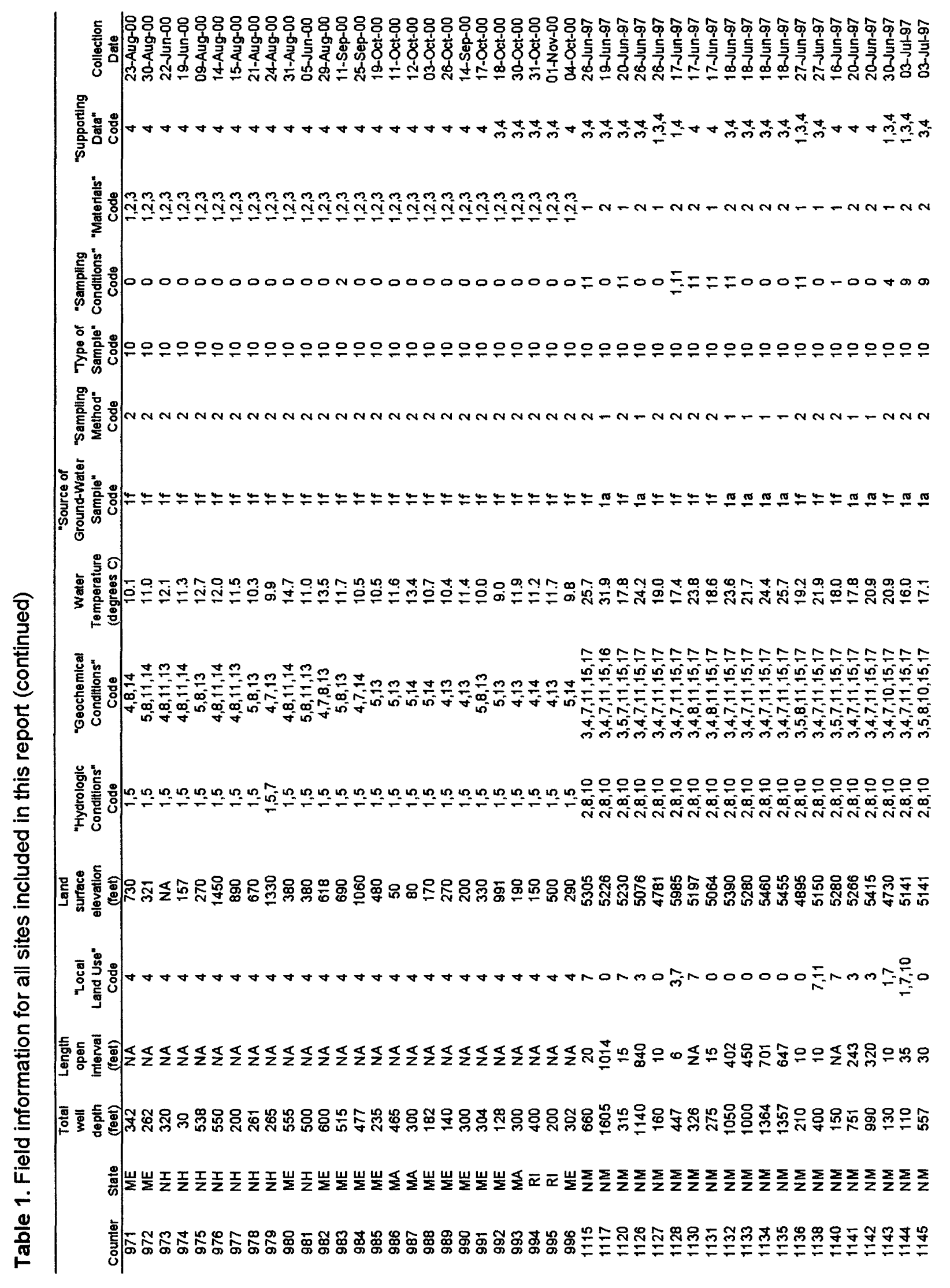




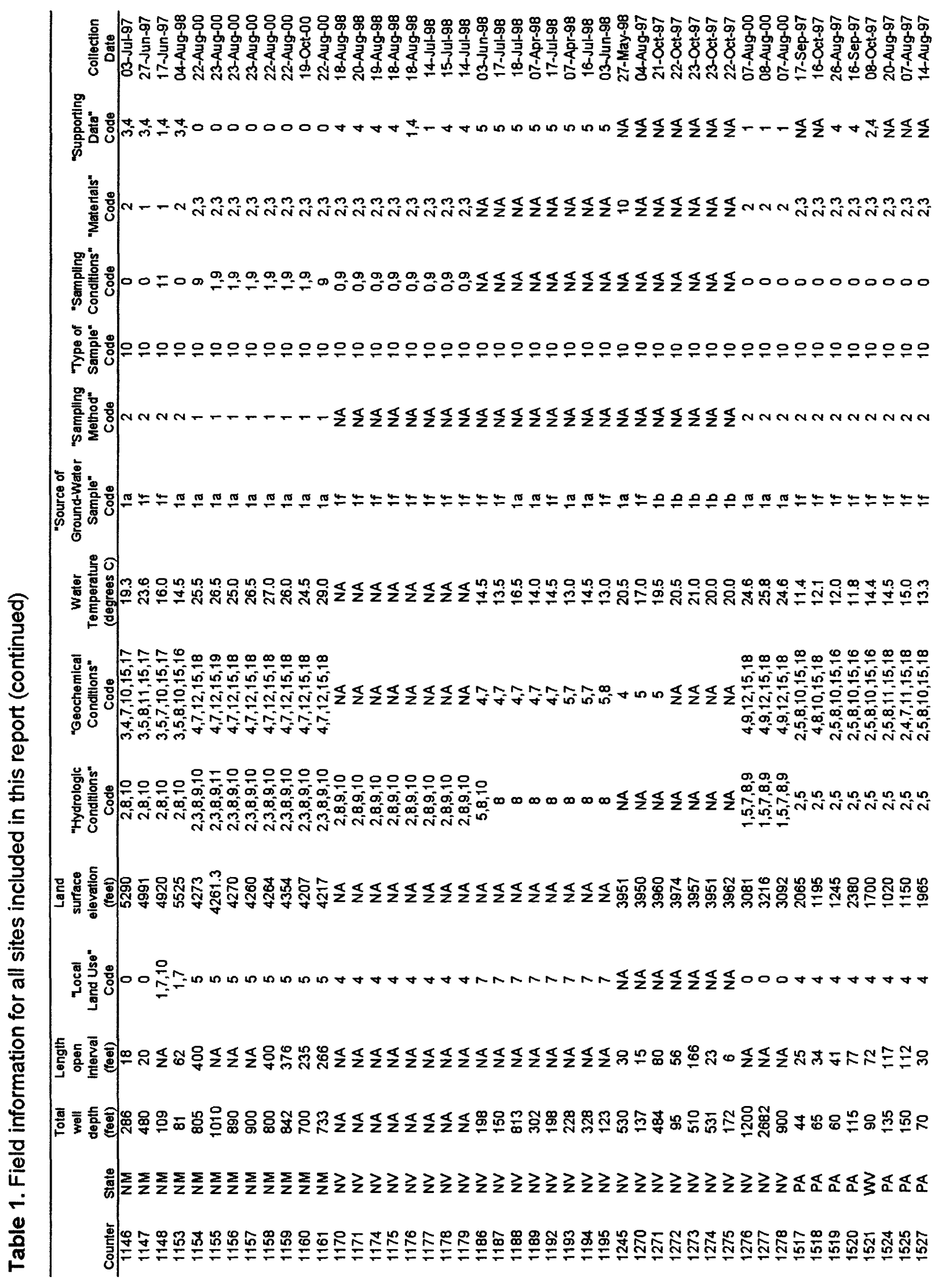




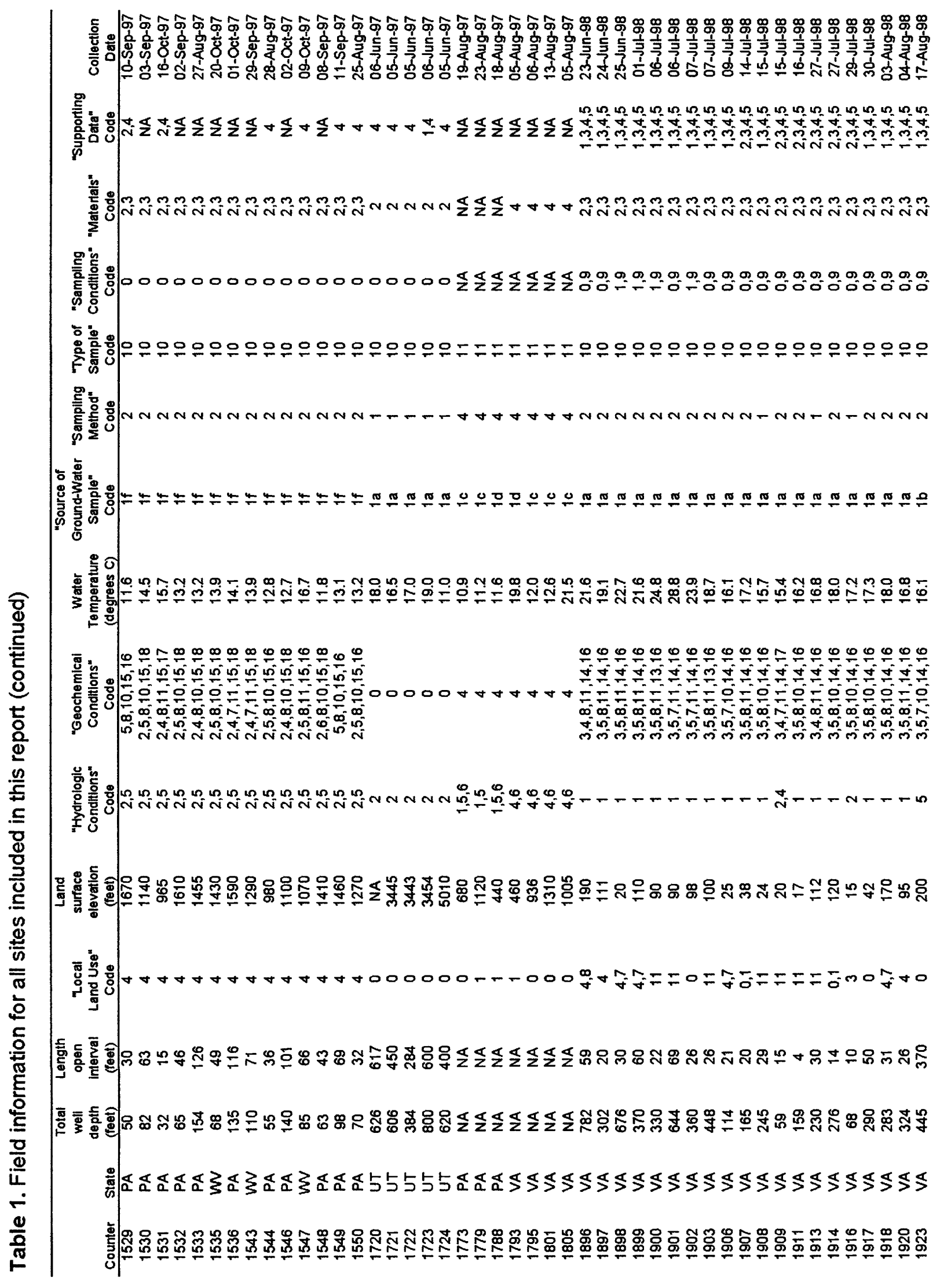




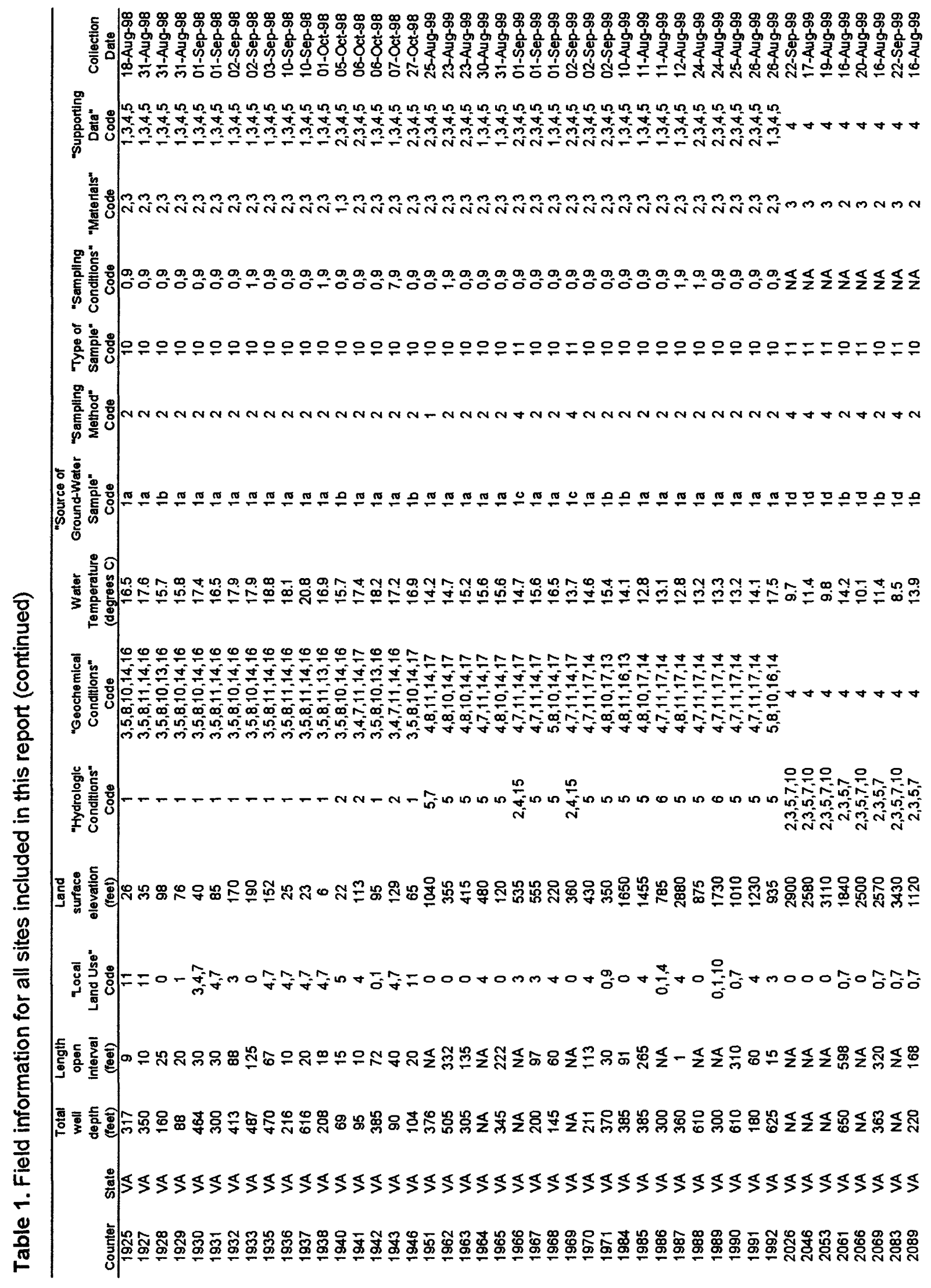




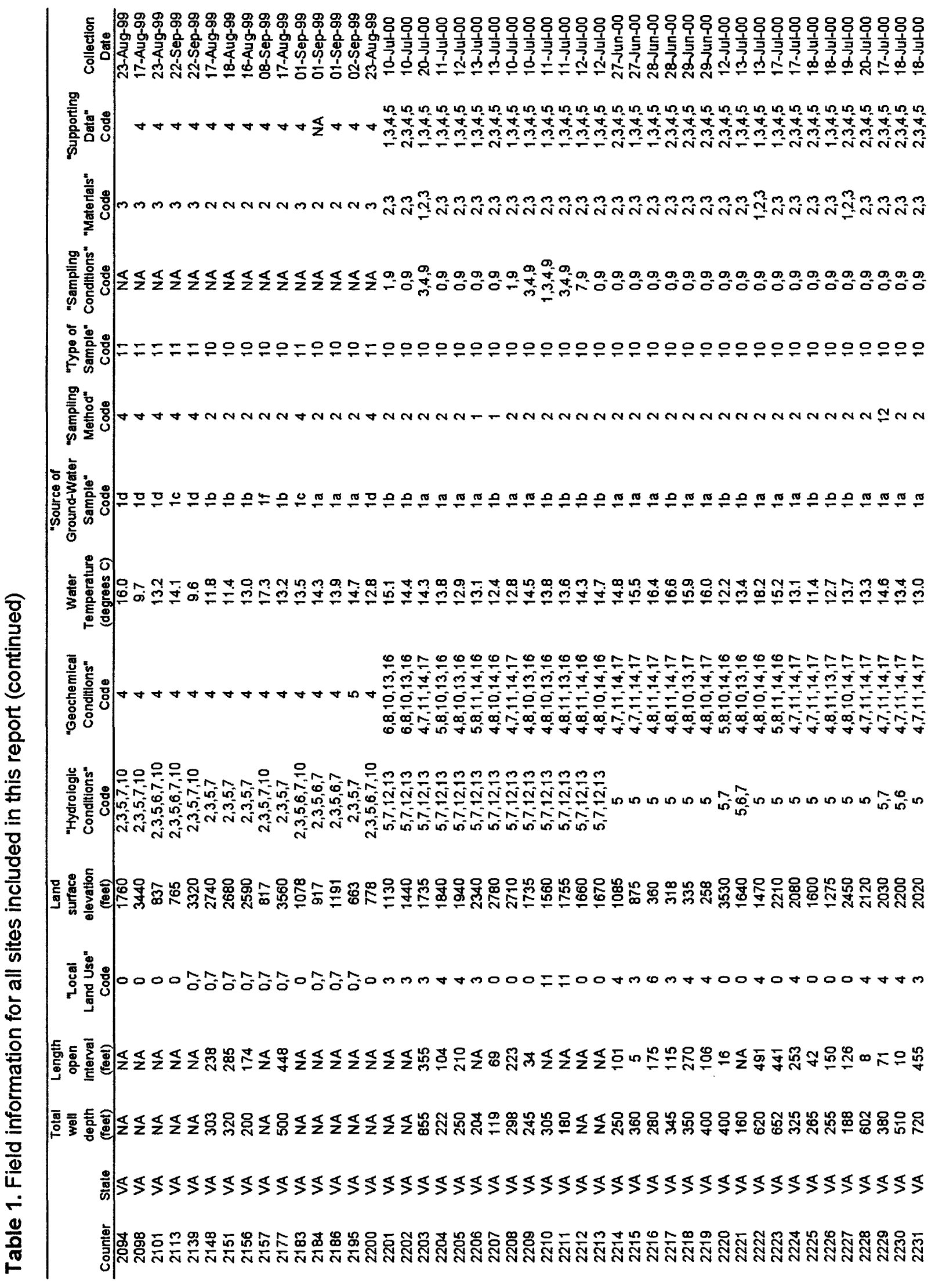




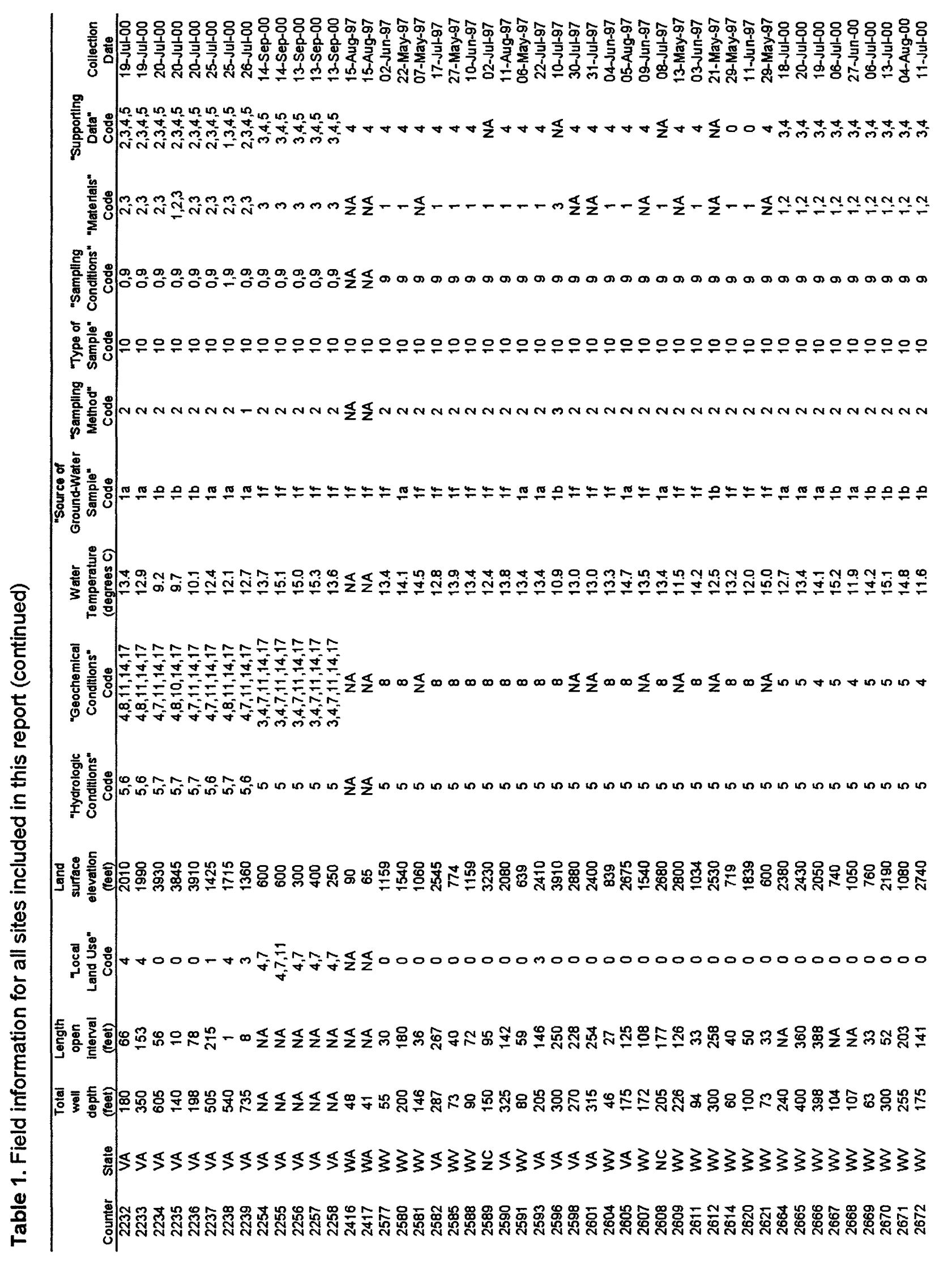




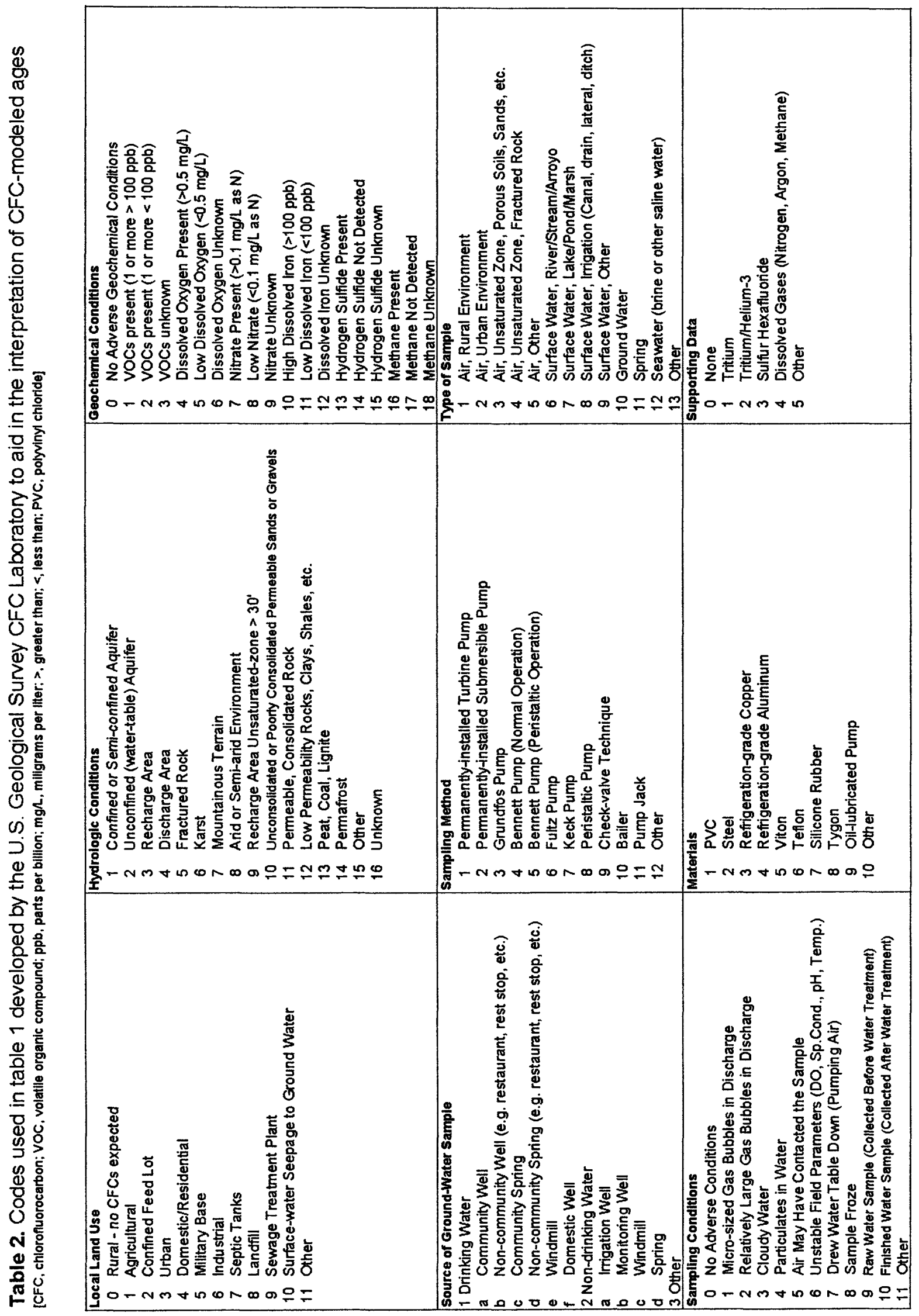




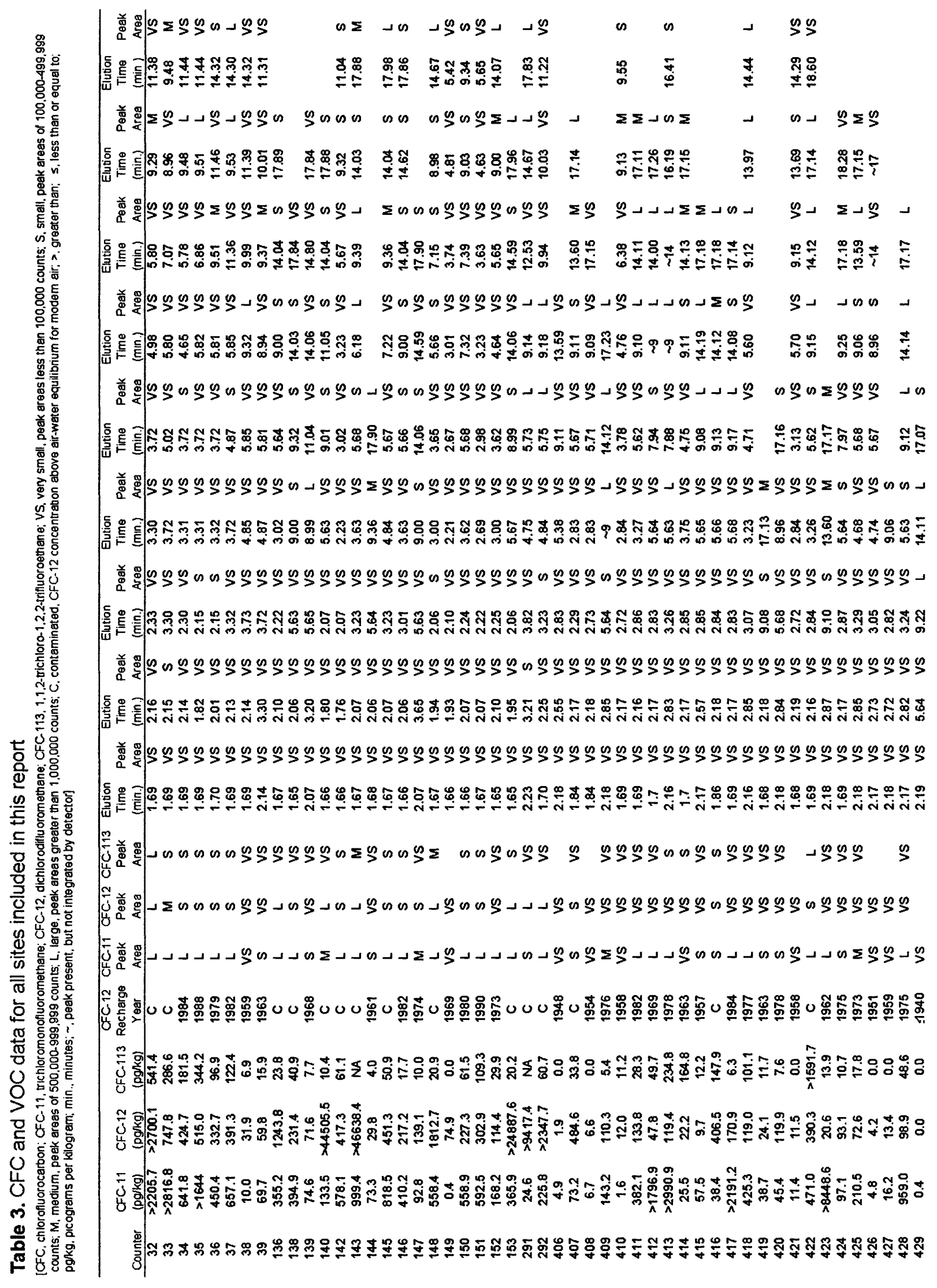




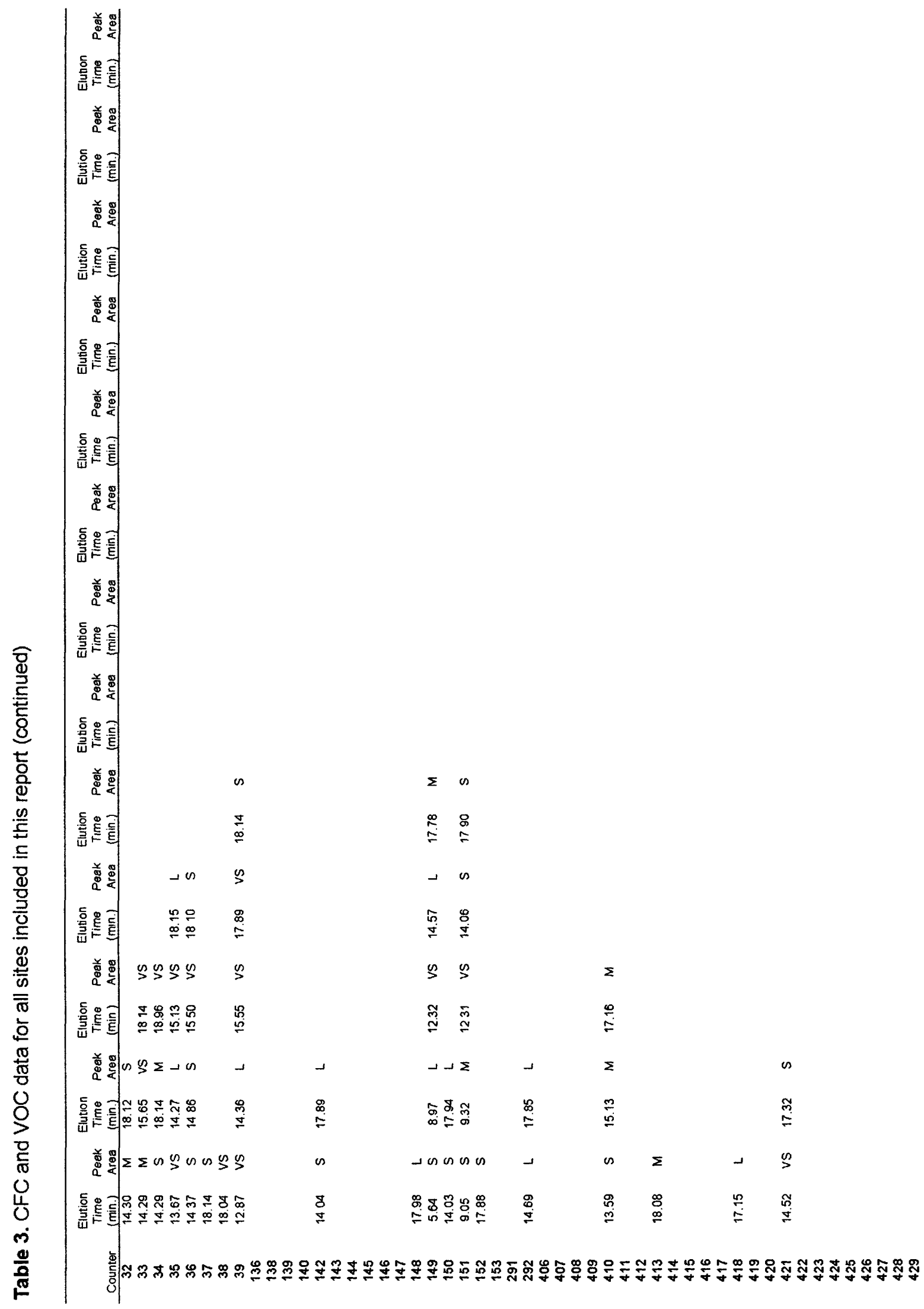




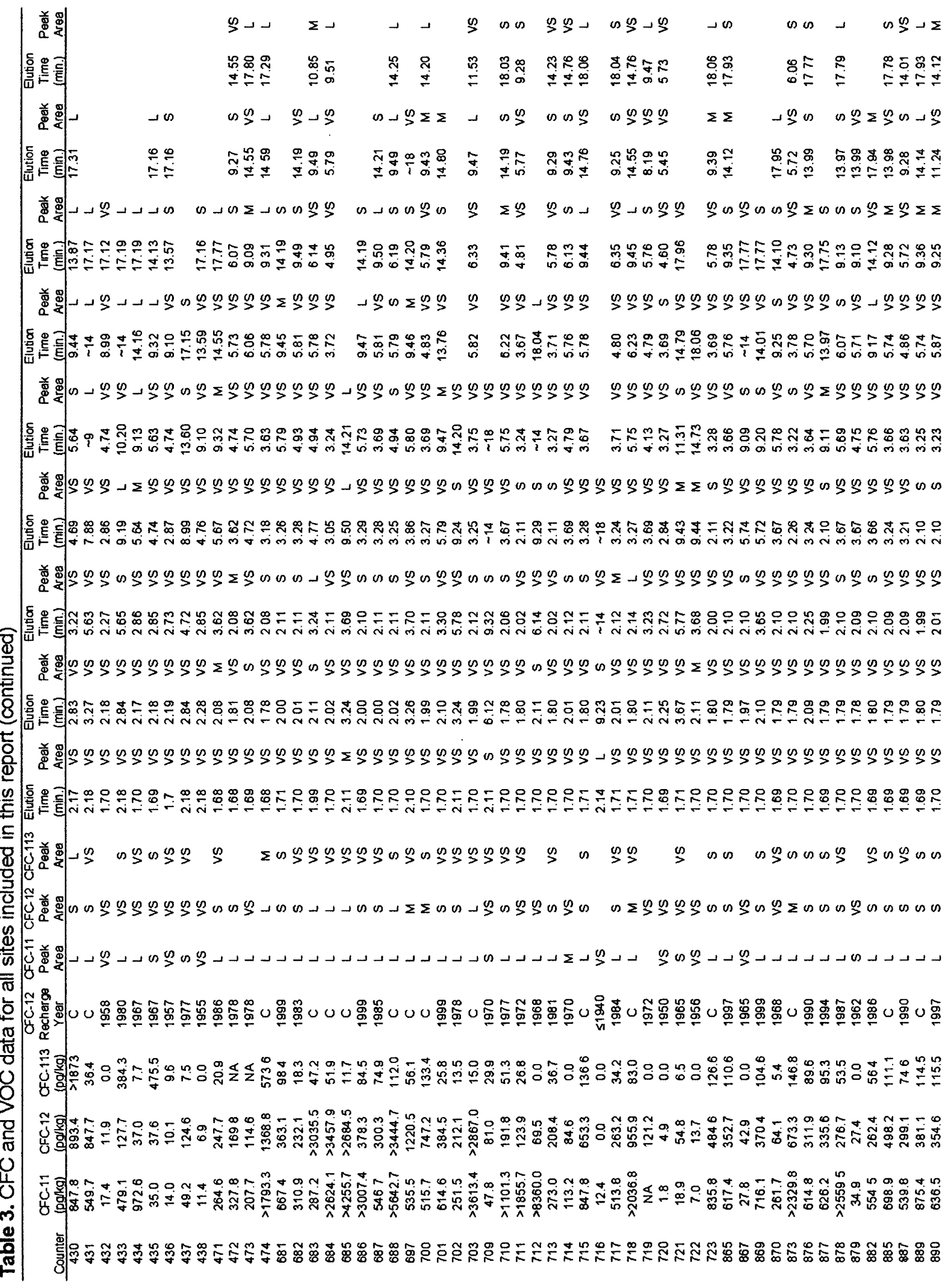




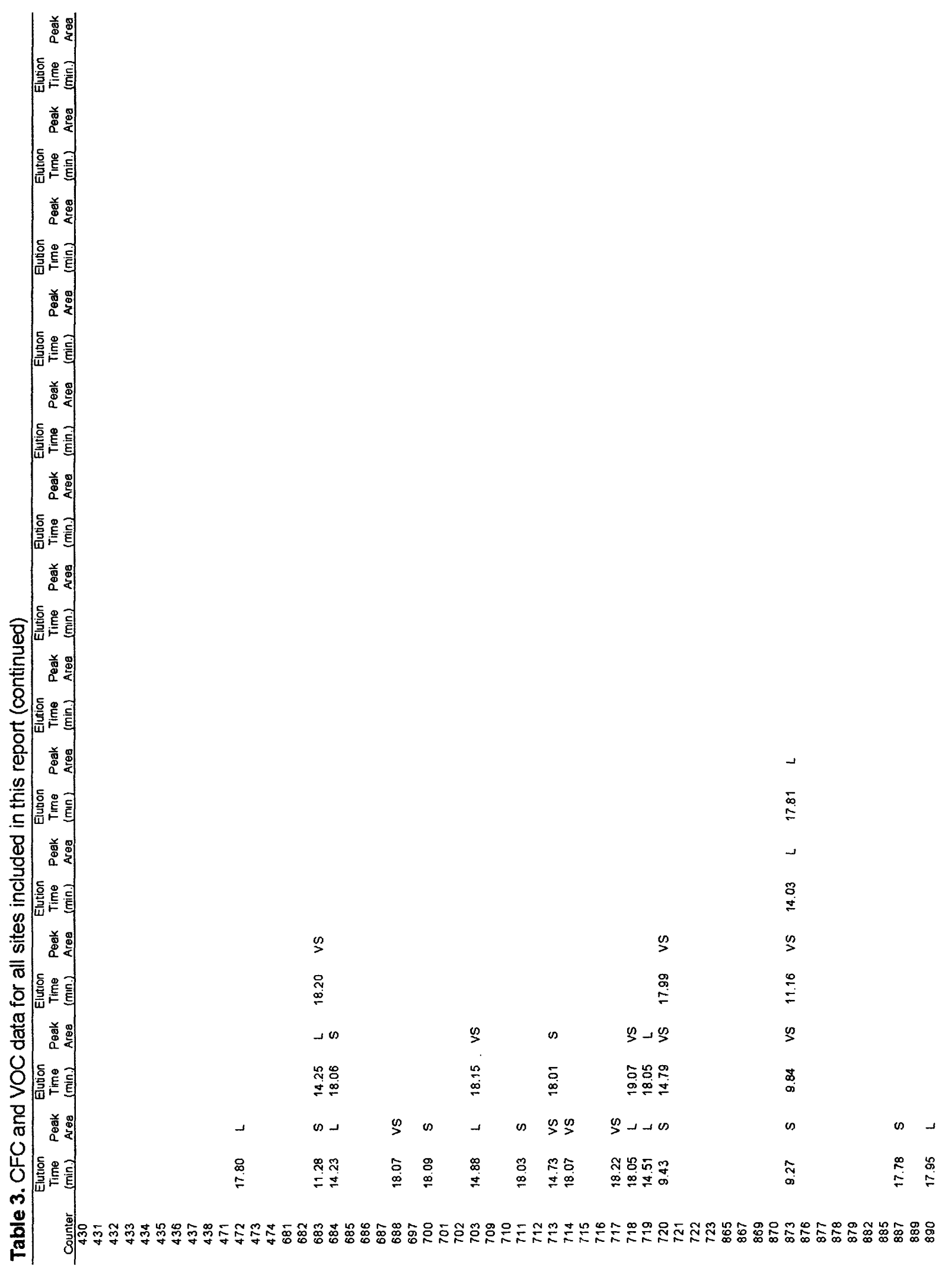




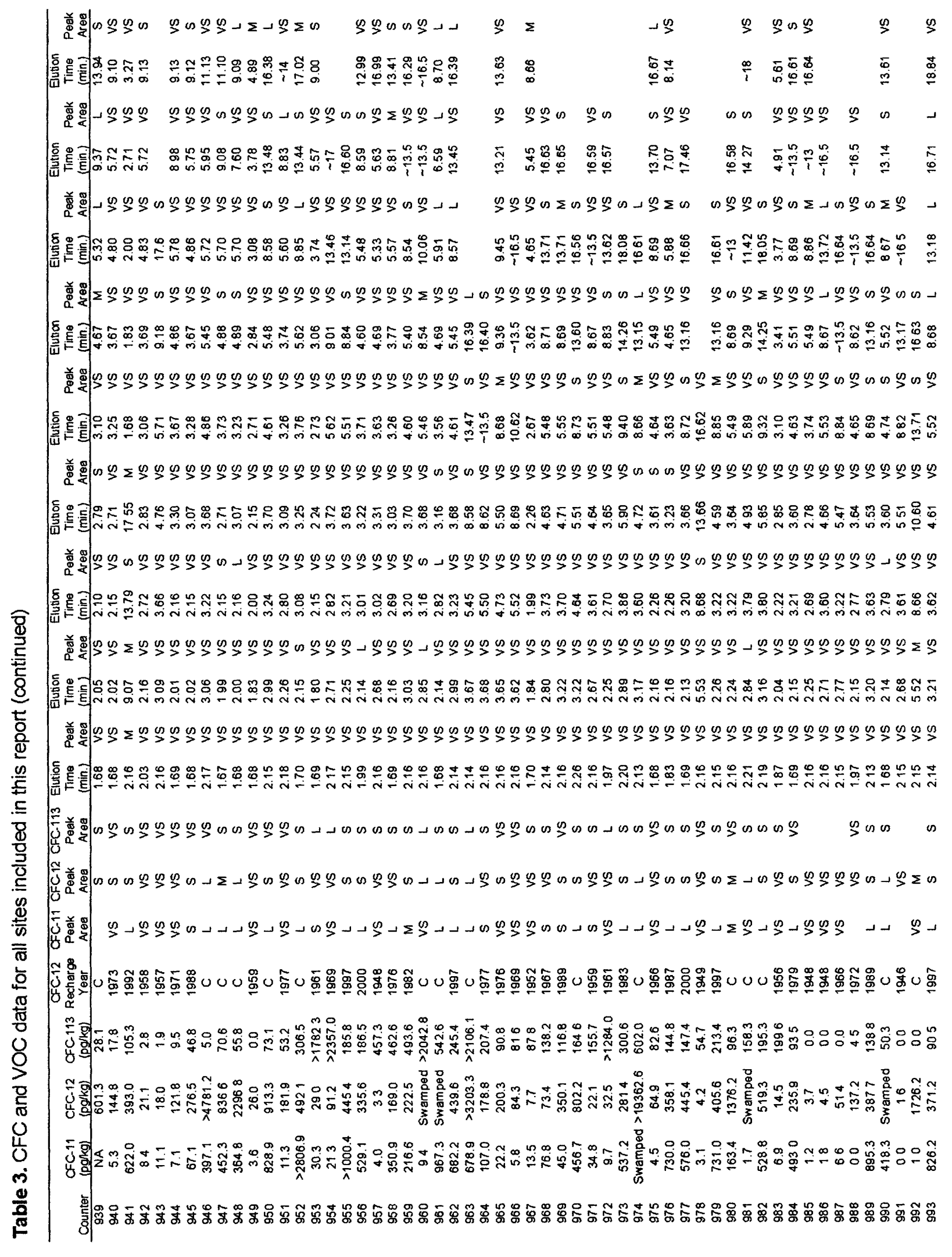




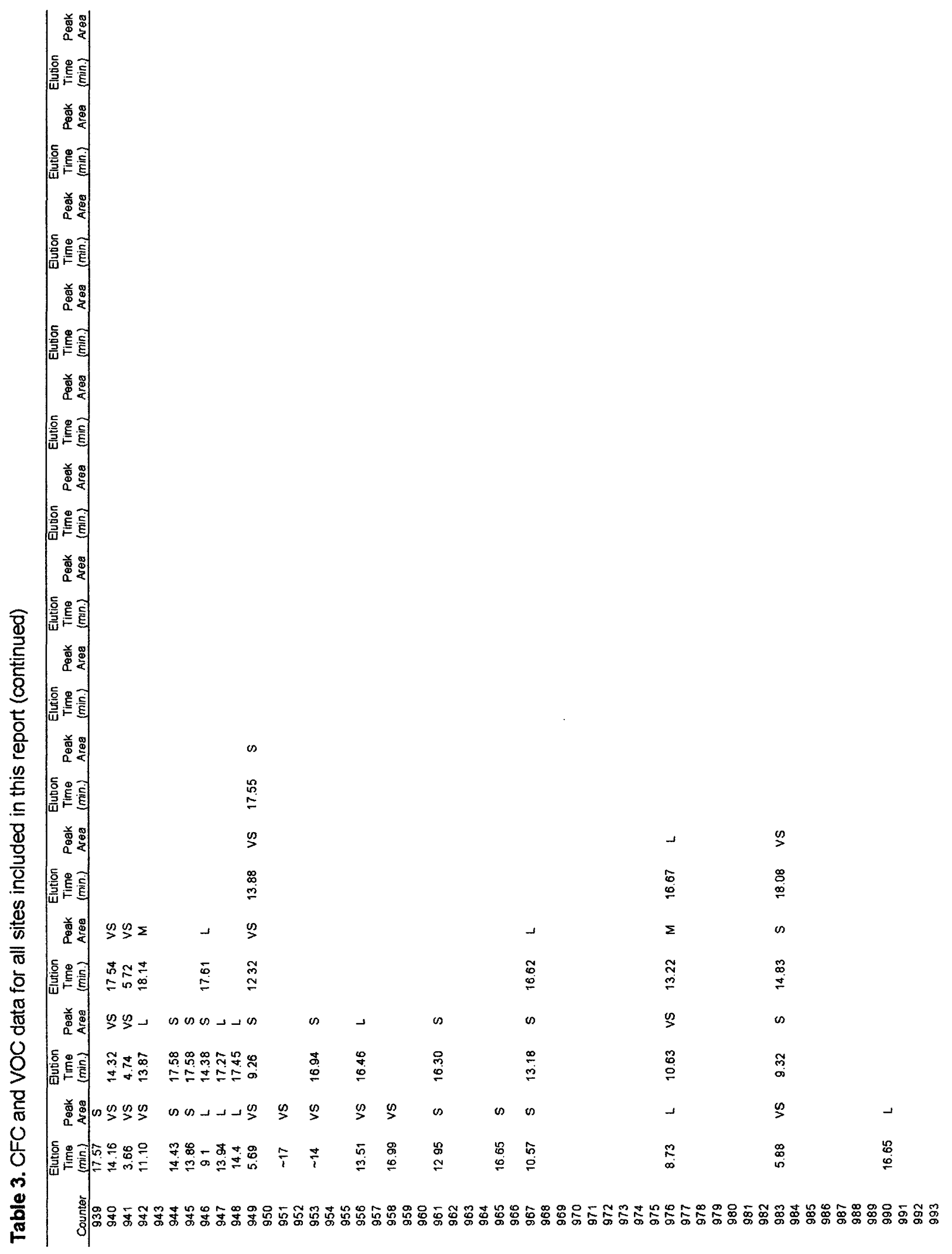




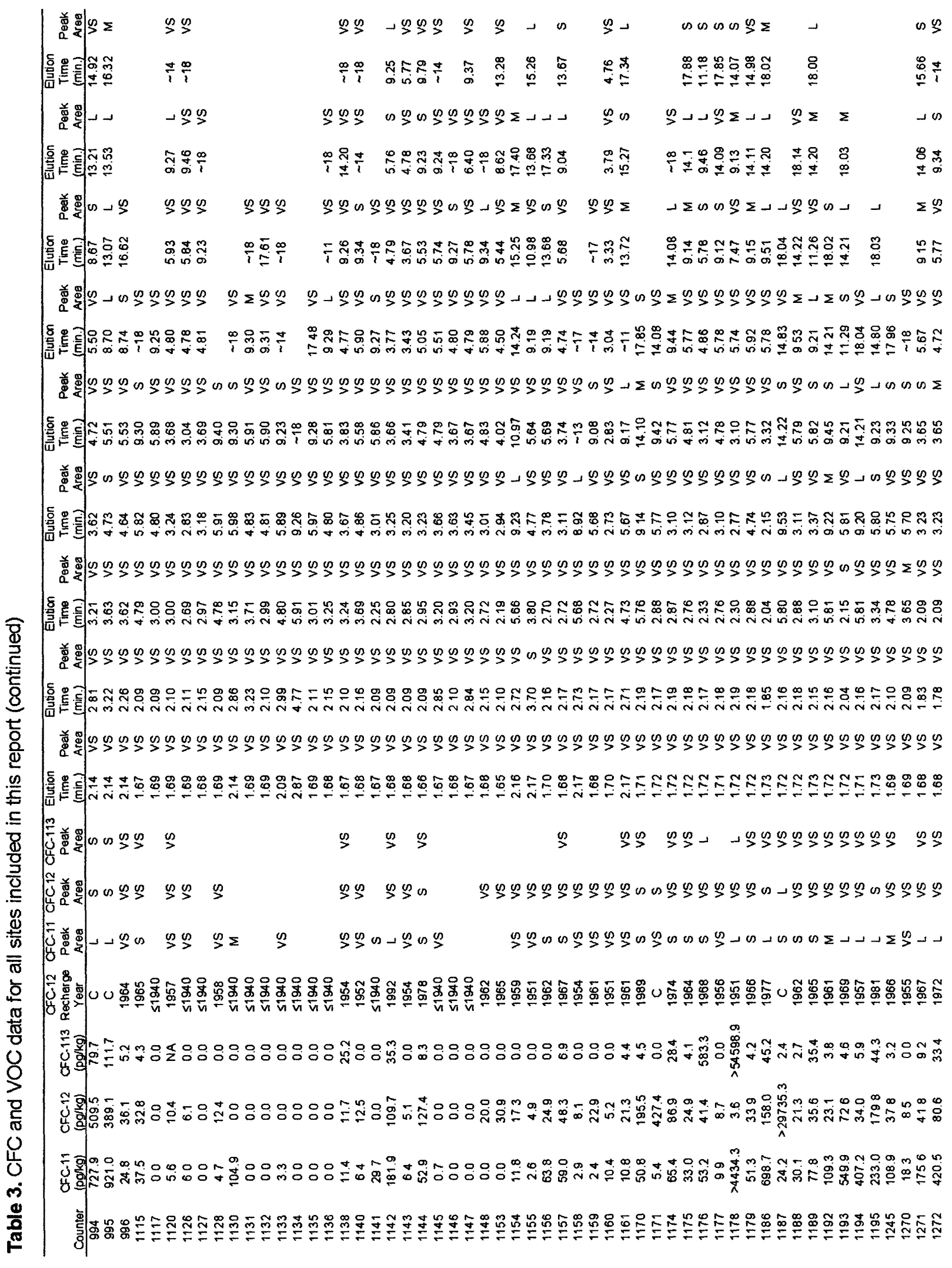




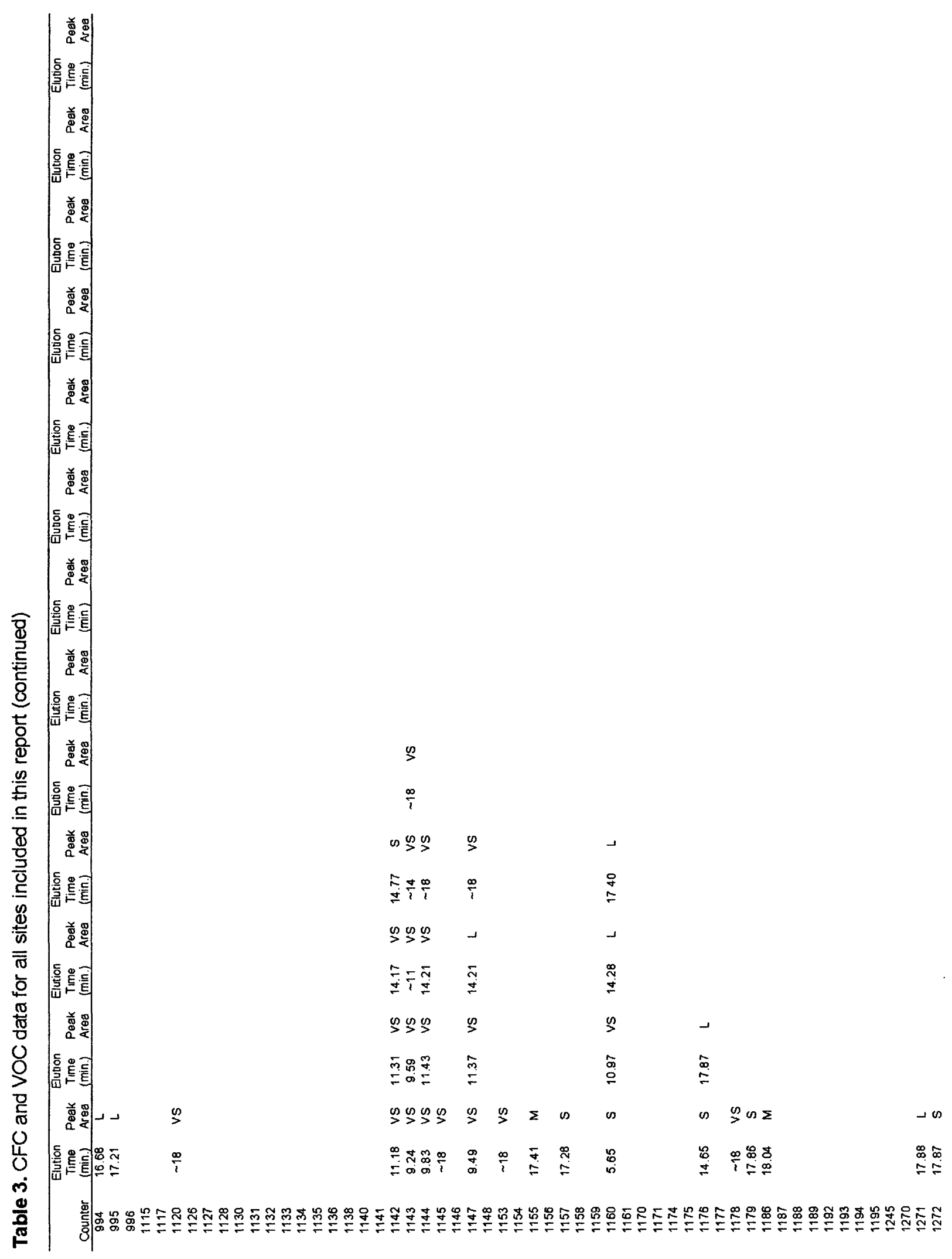




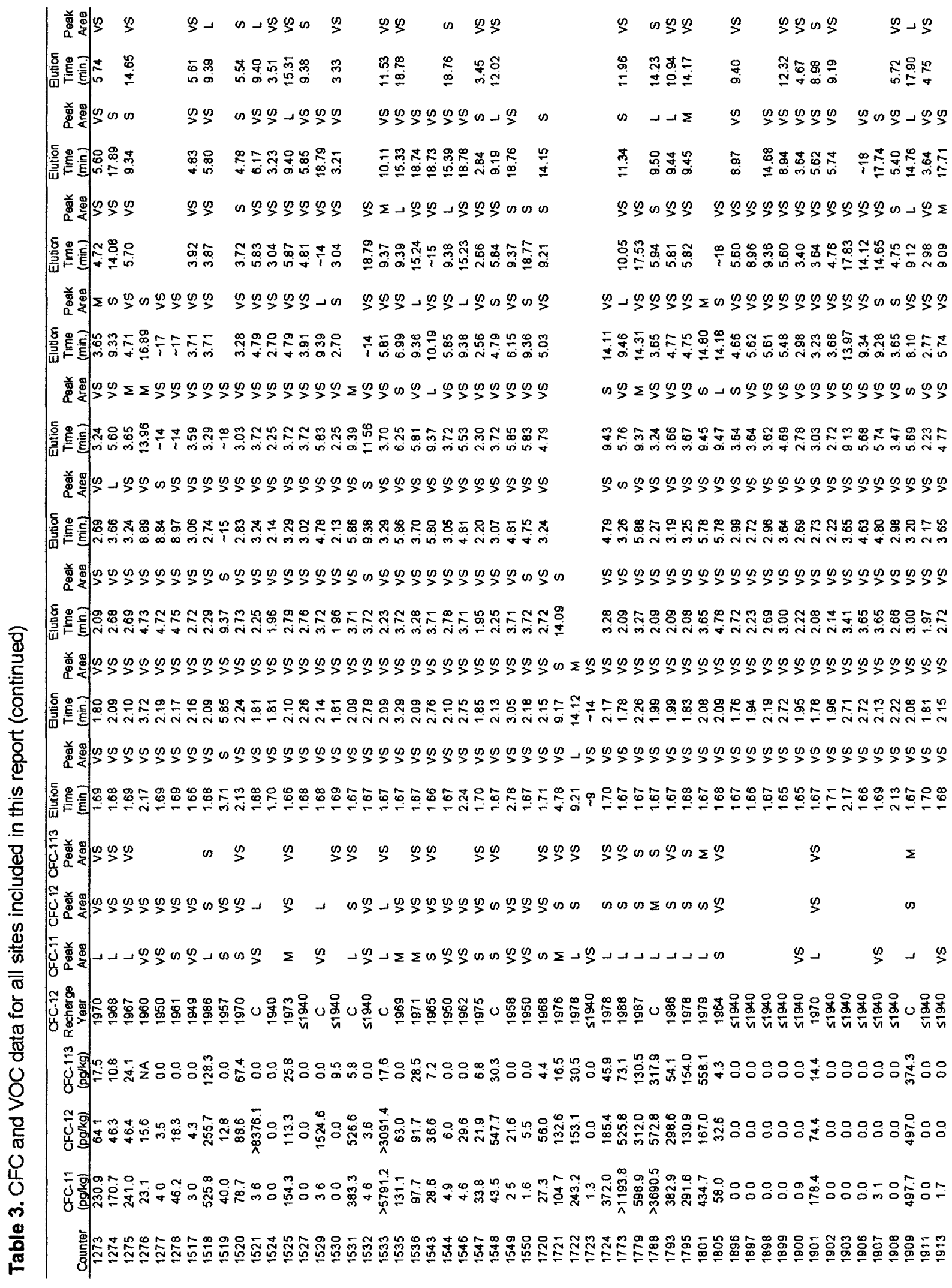




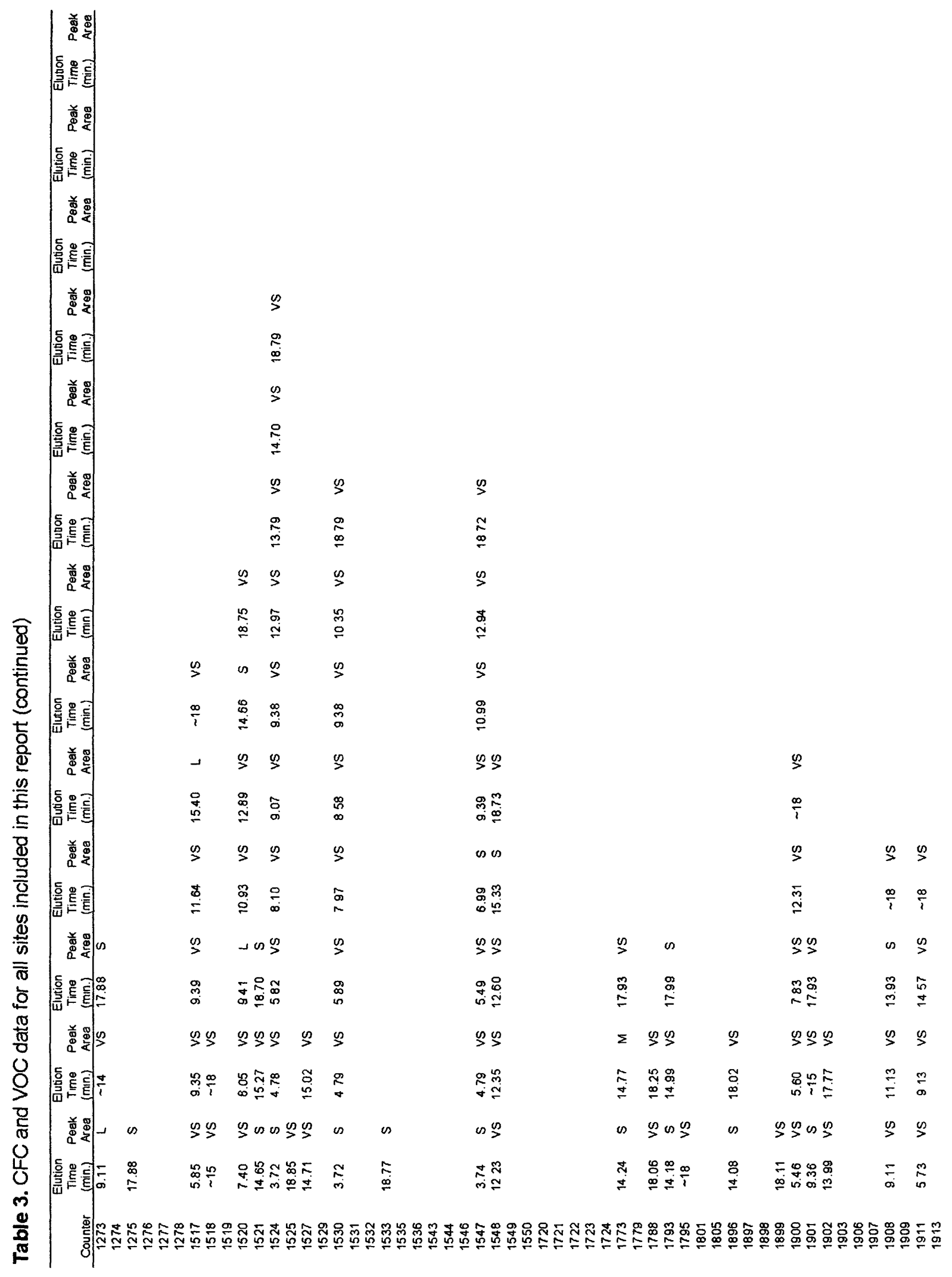




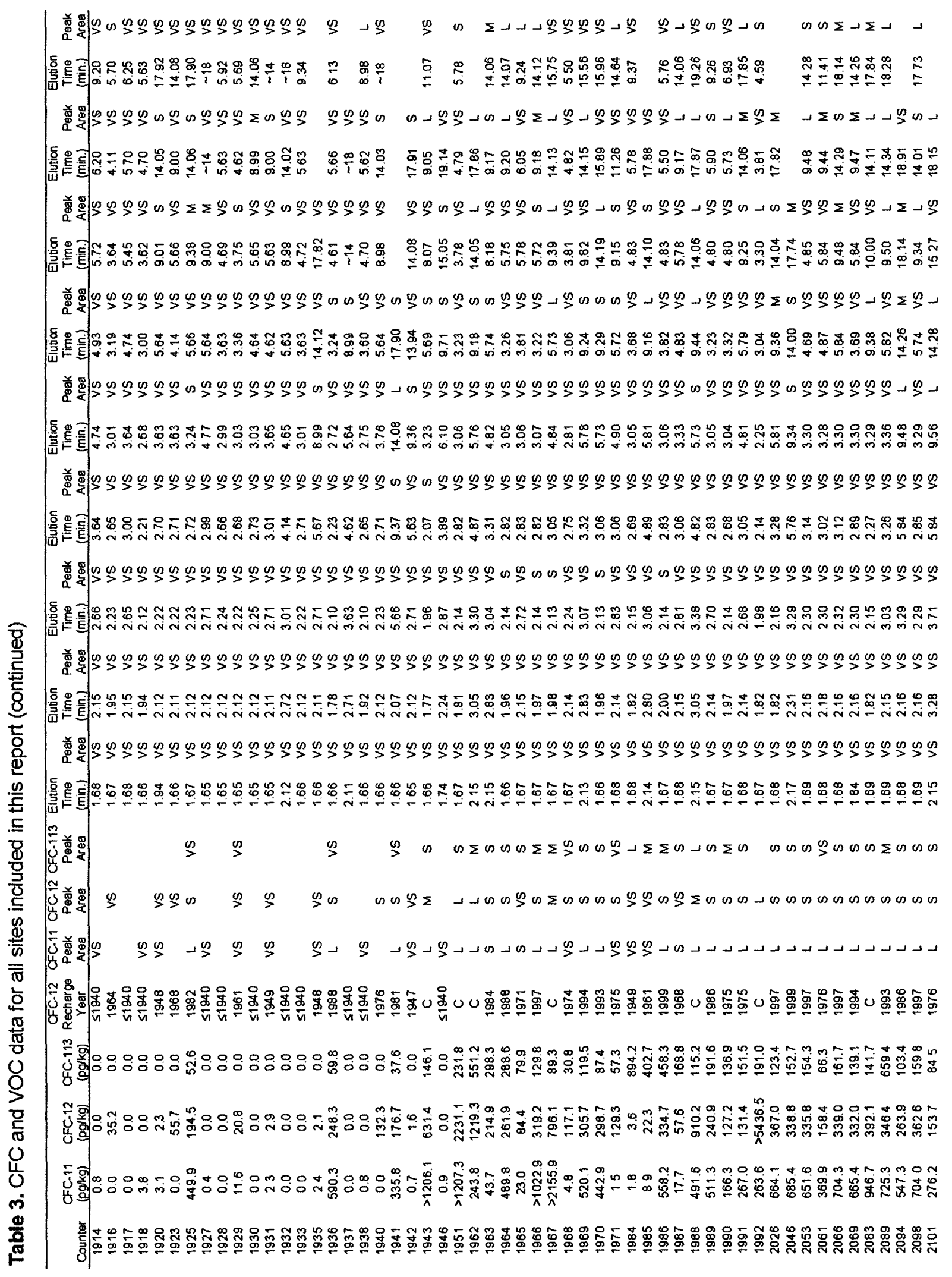




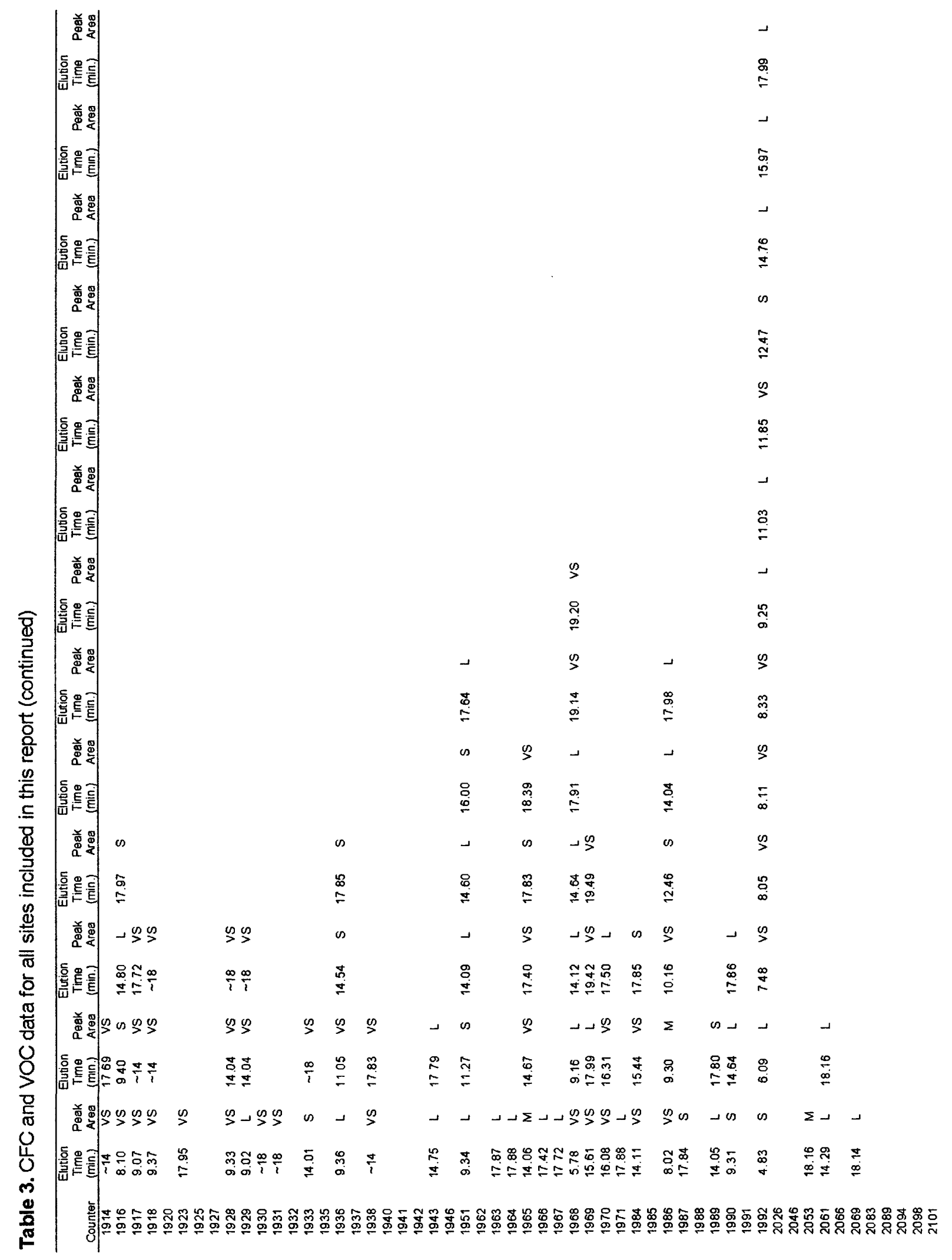




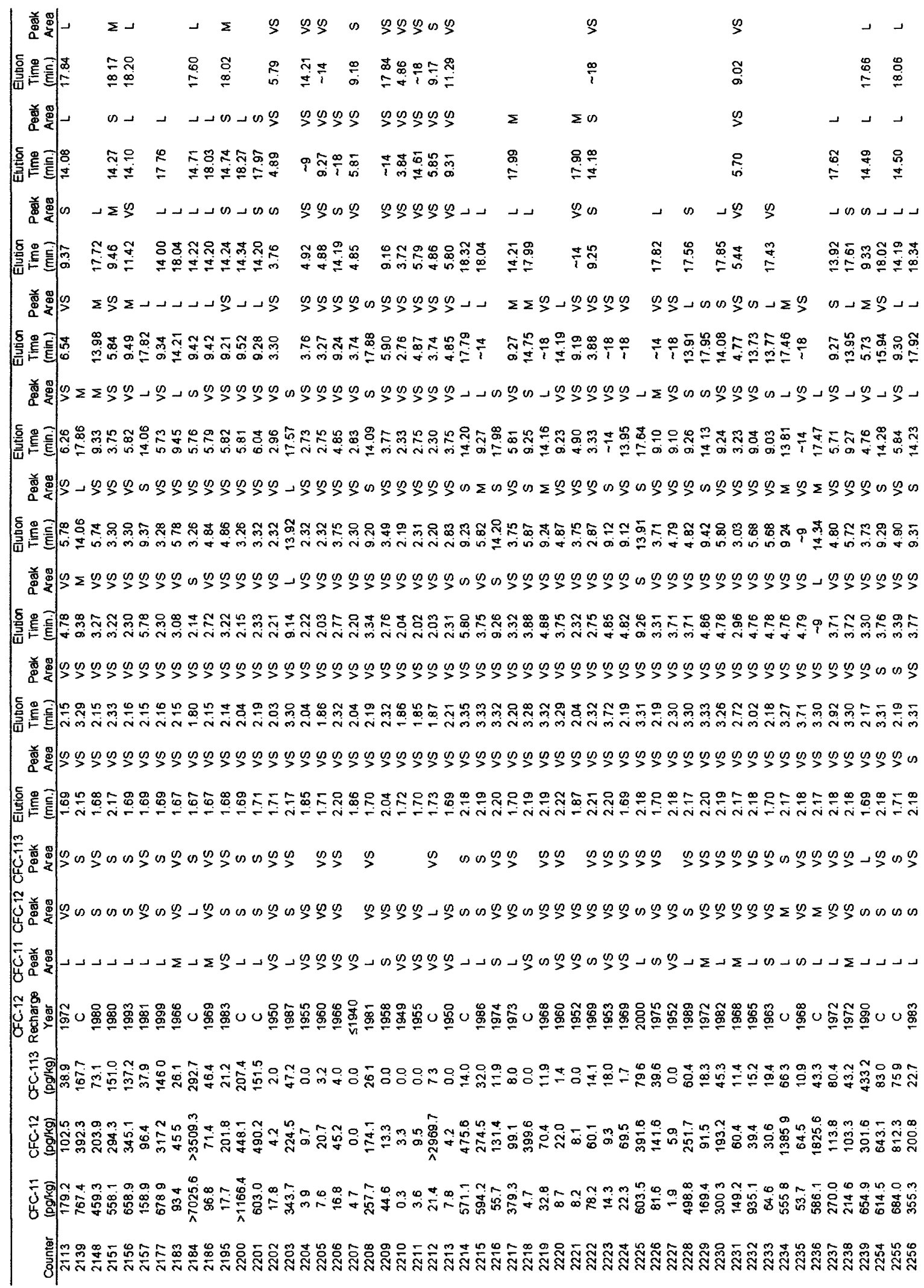




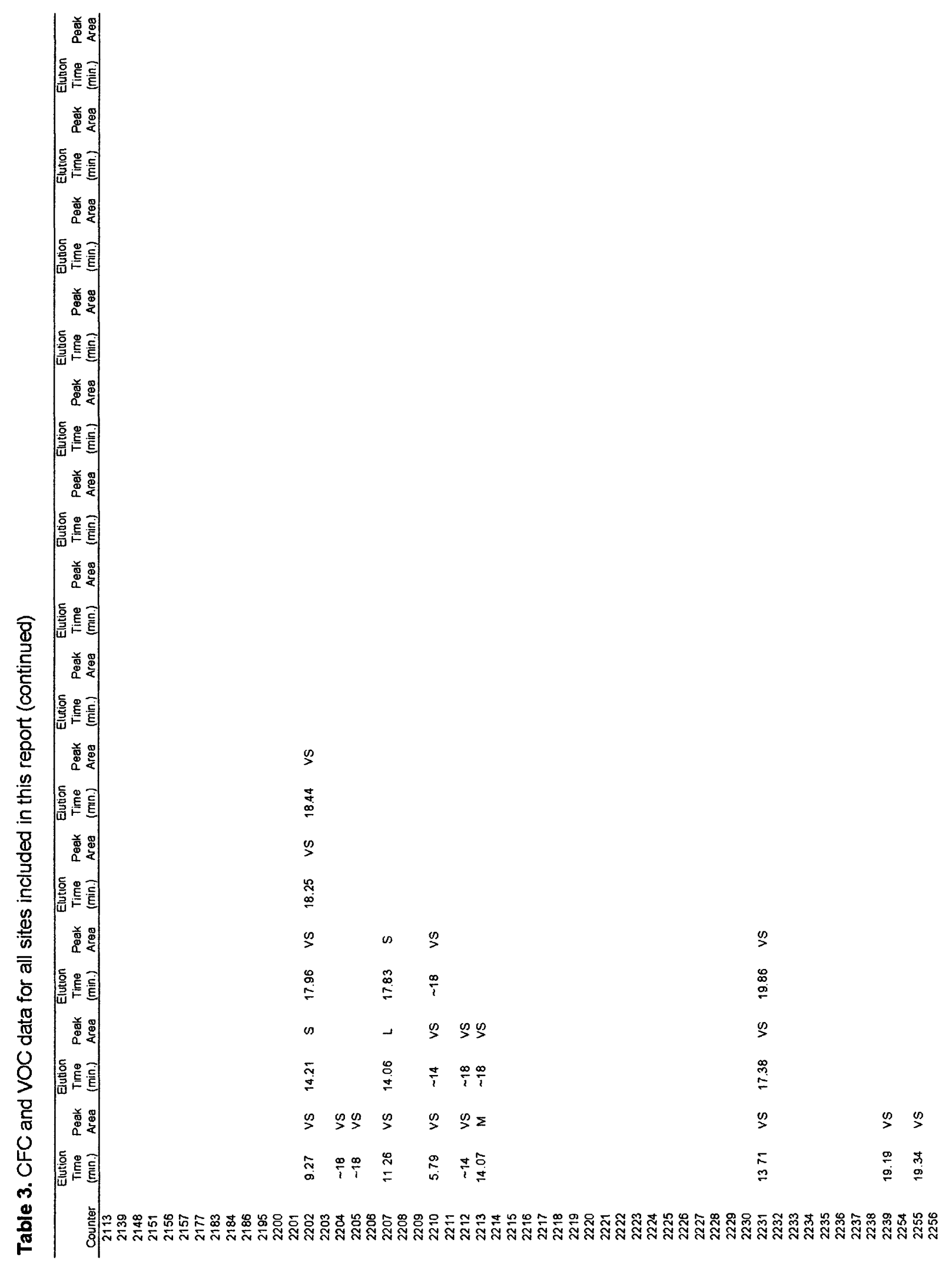




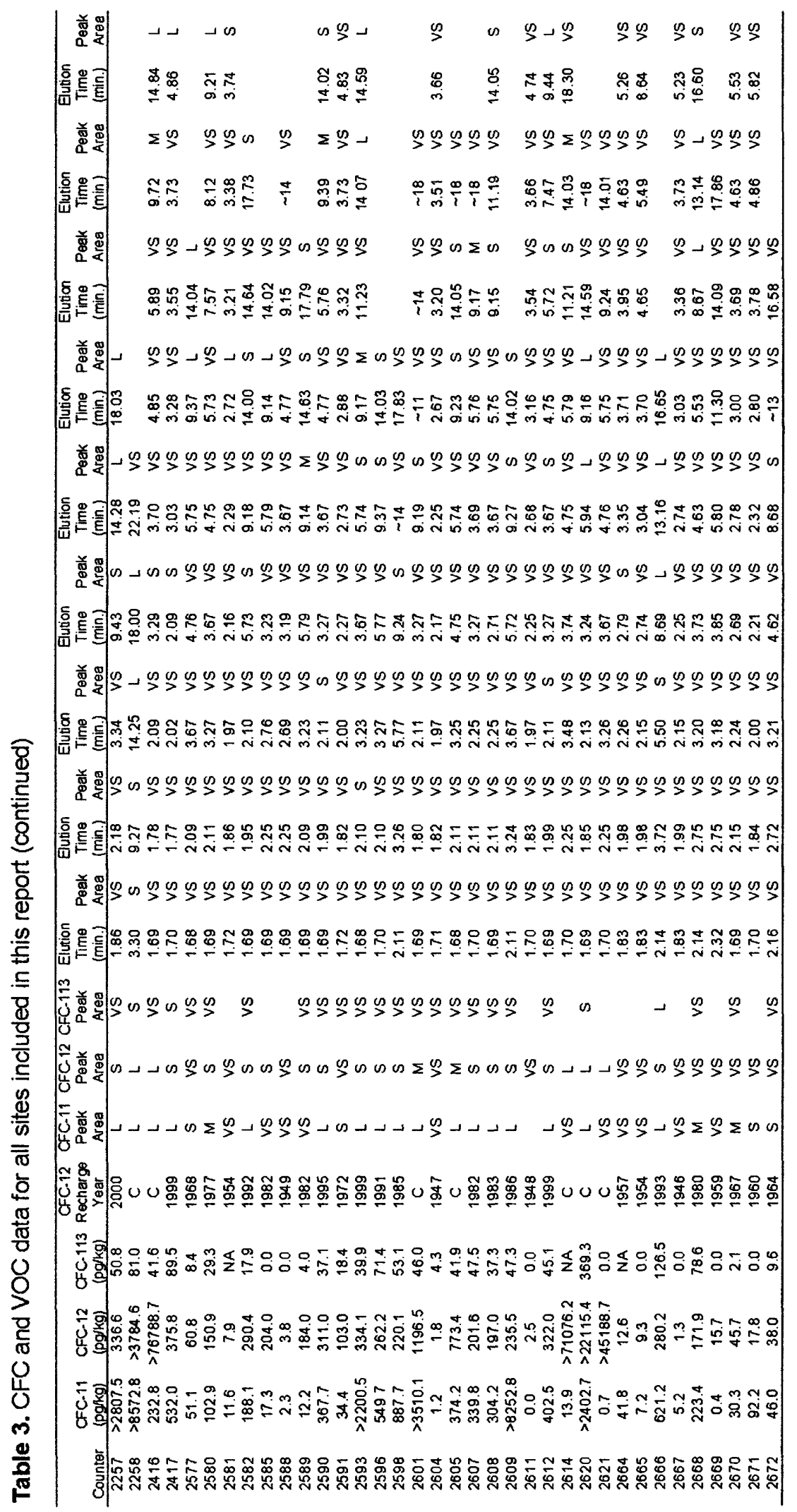




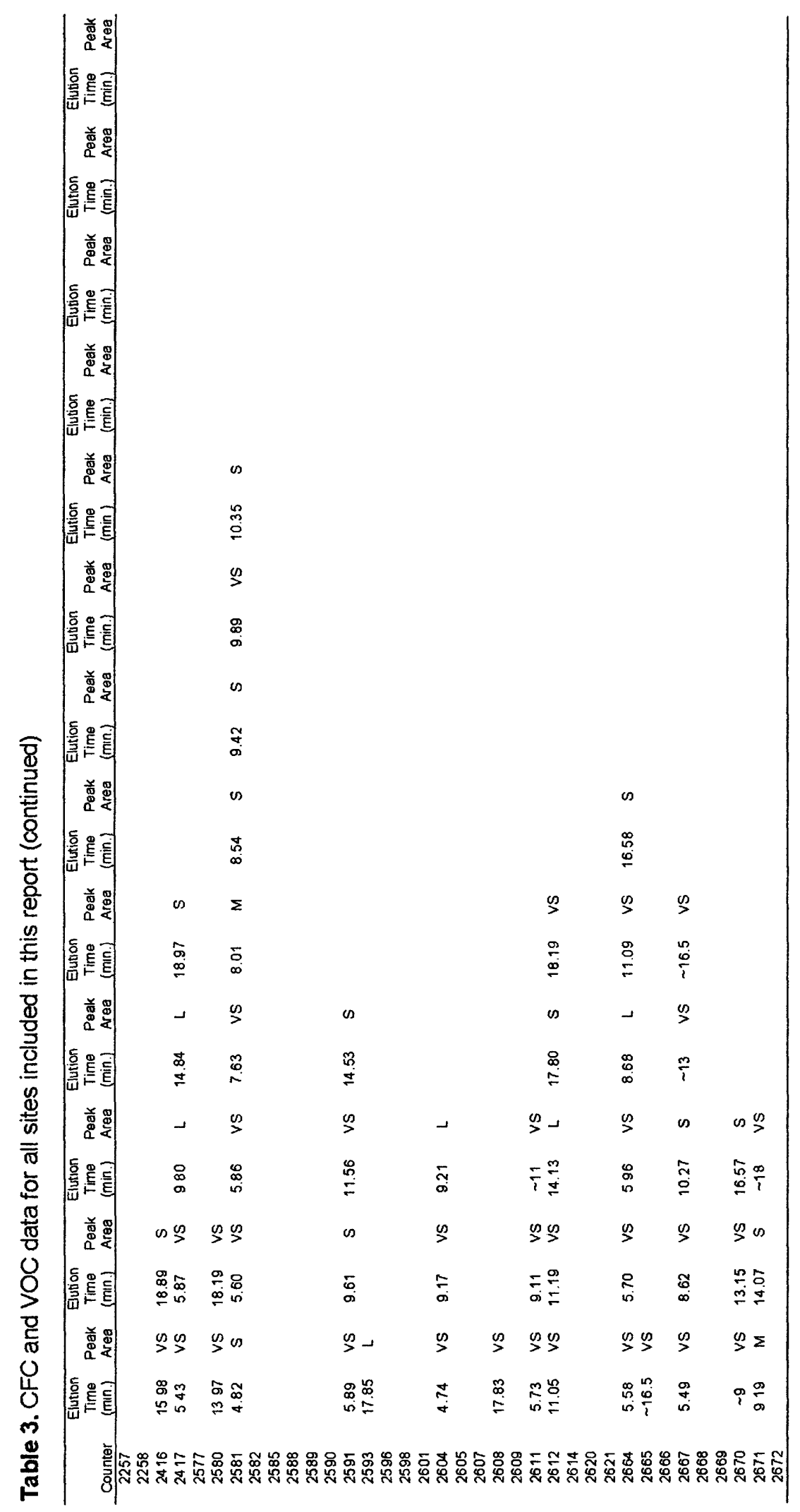




\section{REFERENCES CITED}

Bender, D.A., Zogorski, J.S., Halde, M.J., and Rowe, B.L., 1999, Selection Procedure and Salient Information for Volatile Organic Compounds Emphasized in the National WaterQuality Assessment Program: U.S. Geological Survey Open-File Report 99-182, 32 p.

Busenberg, E., and Plummer, L.N., 1992, Use of chlorofluorocarbons $\left(\mathrm{CCl}_{3} \mathrm{~F}\right.$ and $\mathrm{CCl}_{2} \mathrm{~F}_{2}$ ) as hydrologic tracers and age-dating tools: The alluvium and terrace system of Central Oklahoma: Water Resources Research, v. 28, no. 9, p. 2257-2283.

Lapham, W.W., Moran, M.J., and Zogorski, J.S., 2000, Enhancements of Nonpoint-Source Monitoring Programs to Assess Volatile Organic Compounds in Ground Water of the United States: The American Water Resources Association, v. 36, no. 6, p. 1321-1334.

Mlay, M., 1990, Management Controls of Volatile Organic Compounds in Groundwater Protection, in Ram, N.M., Christman, R.F., and Cantor, K.P., eds., Significance and Treatment of Volatile Organic Compounds in Water Supplies, Lewis Publishers, Inc., p. 15-36.

Moran, M.J., Lapham, W.W., Rowe, B.L., and Zogorski, J.S., 2002, Occurrence and Status of Volatile Organic Compounds in Ground Water from Rural, Untreated, Self-supplied Domestic Wells in the United States, 1986-99: U.S. Geological Survey Water-Resources Investigations Report 02-4085, 51 p.
Moran, M.J., Zogorski, J.S., and Squillace, P.J., 1999, MTBE in Ground Water of the United States-Occurrence, Potential Sources, and Long-Range Transport, in Proceedings of the American Water Works Association, Norfolk, VA, Sept. 26-29, 1999:

American Water Works Association, CD-ROM.

Plummer, L.N., and Busenberg, E., 2000, Chlorofluorocarbons, in Cook, P.G., and Herzeg, A., eds., Environmental Tracers in Subsurface Hydrology, Chapter 15, Kluwer Academic Press, p. $441-478$.

Plummer, L.N., and Friedman, L.C., 1999, Tracing and Dating Young Ground Water: U.S. Geological Survey Fact Sheet 134-99, 4 p. (see http://water.usgs.gov/pubs/FS/FS134-99/ ).

Rowe, B., Grady, S., Zogorski, J., Koch, B., and Tratnyek, P., 2001, National Survey of MTBE, Other Ether Oxygenates, and Other VOCs in Community Drinking-Water Sources: U.S. Geological Survey Open File Report 01-399, 1 p.

Shapiro, S.D., Busenberg, E., Focazio, M., and Plummer, L.N., in press, Historical Trends in Occurrence and Atmospheric Inputs of Halogenated Volatile Organic Compounds in Untreated Ground Water Used as a source of Drinking Water: The Science of the Total Environment.

Shapiro, S.D., Plummer, L.N., Focazio, M., Busenberg, E., Kirkland, W., and Fernandez, M., 2002, VOC Occurrence in Drinking Water from the United States: Results from Archived Chromatograms and Water 
Samples, 1989-2000: U.S.

Geological Survey Water-Resources Investigations Report 02-4173, 20 p.

Squillace, P.J., Moran, M.J., Lapham, W.W., Price, C.V., Clawges, R.M., and Zogorski, J.S., 1999, Volatile Organic Compounds in Untreated Ambient Groundwater of the United States, 1985-95: Environmental Science and Technology, v. 33, no. 23, p. 4176-4187.

Squillace, P.J., Scott, J.C., Moran, M.J., Nolan, B.T., and Kolpin, D.W., 2002, VOCs, Pesticides, Nitrate, and Their Mixtures in Groundwater Used for Drinking Water in the United States: Environmental Science and Technology, v. 36, no. 9, p. 19231930.

Stackelberg, P.E., Kauffman, L.J., Baehr, A.L., and Ayers, M.A., 2000, Comparison of Nitrate, Pesticides, and Volatile Organic Compounds in Samples from Monitoring and Public-Supply Wells, KirkwoodCohansey Aquifer System, Southern New Jersey: U.S. Geological Survey Water-Resources Investigations Report 00-4123, 51 p.

Westrick, J.J., 1990, National Surveys of Volatile Organic Compounds in Ground and Surface Waters, in Ram, N.M., Christman, R.F., and Cantor, K.P., eds., Significance and Treatment of Volatile Organic Compounds in Water Supplies, Lewis Publishers, Inc., p. 103-125.

Zogorski, J., Morgan, M.J., and Hamilton, P.A., 2001, MTBE and Other Volatile Organic Compounds- New Findings and Implications on the Quality of Source Waters Used for Drinking-Water Supplies: U.S.
Geological Survey Fact Sheet FS105-01, 2 p. 


$$
\cdot
$$


